Article

\title{
True 2-D Resistivity Imaging from Vertical Electrical Soundings to Support More Sustainable Rural Water Supply Borehole Siting in Malawi
}

\author{
Romain Leborgne ${ }^{1,2, *}$, Michael O. Rivett ${ }^{1, *} *$ D , Gift J. Wanangwa ${ }^{3}$, Philippe Sentenac ${ }^{1}$ and Robert M. Kalin ${ }^{1}(\mathbb{D}$ \\ 1 Department of Civil and Environmental Engineering, University of Strathclyde, Glasgow G1 1XJ, UK; \\ philippe.sentenac@strath.ac.uk (P.S.); robert.kalin@strath.ac.uk (R.M.K.) \\ 2 Drilcorp Ltd., Seaham, County Durham SR7 8SW, UK \\ 3 Groundwater Division, Water Resources Department, Ministry of Forestry and Natural Resources, \\ Private Bag 390, Lilongwe 3, Malawi; gjwanangwa@gmail.com \\ * Correspondence: romain.leborgne@drilcorp.com (R.L.); michael.rivett@strath.ac.uk (M.O.R.)
}

check for updates

Citation: Leborgne, R.; Rivett, M.O.; Wanangwa, G.J.; Sentenac, P.; Kalin, R.M. True 2-D Resistivity Imaging from Vertical Electrical Soundings to Support More Sustainable Rural Water Supply Borehole Siting in Malawi. Appl. Sci. 2021, 11, 1162. https://doi.org/ 10.3390/app11031162

Received: 3 December 2020

Accepted: 22 January 2021

Published: 27 January 2021

Publisher's Note: MDPI stays neutra with regard to jurisdictional claims in published maps and institutional affiliations.

Copyright: (c) 2021 by the authors Licensee MDPI, Basel, Switzerland. This article is an open access article distributed under the terms and conditions of the Creative Commons Attribution (CC BY) license (https:// creativecommons.org/licenses/by/ $4.0 /)$.
Featured Application: A low-cost, developing-country-accessible geophysical survey method to aid water-supply borehole siting was developed and applied in Malawi. The method uses multiple vertical electrical soundings (VESs) to generate true 2-D resistivity cross-sections images of the geological subsurface detail comparable to more expensive geophysical techniques with results far superior to 1-D hydrogeophysical approaches currently used in Malawi. Technology adoption will greatly facilitate local targeting of aquifer resources and permit more sustainable siting of supply boreholes that is vital to Malawi's majority rural population who are predominantly reliant on groundwater for safe drinking water supply.

Abstract: To improve borehole siting for rural water supply, an advanced resistivity method was adapted for developing country use and demonstrated in Malawi. The method was designed to be low cost, developing-country accessible, efficient. It allows single or multiple operators to acquire the multiple vertical electrical soundings (VESs) required that are inverted together in 2-D, to give a true cross-section of subsurface resistivity. Application at four sites generated true cross-sections of subsurface resistivity to around $100 \mathrm{~m}$ depth relevant to groundwater-resource investigation. A wide range of (hydro)geological features was identified, including fractured/weathered basement, gneiss domes, well-developed fault zones and several types of deltaic deposits. Imaging performance appears comparable to that of 2-D surface ERT (electrical resistivity tomography) that uses more expensive equipment, often unaffordable in developing countries. Based on the subsurface configurations determined and hydrogeological conceptualisation subsequently undertaken, the local aquifer potential could be evaluated, thereby providing a decision-making basis for future borehole siting at the sites surveyed. The technology is far superior to conventional 1-D VES, electromagnetic profiling or magnetic profiling currently used for borehole siting in Malawi. Technology adoption currently under consideration nationally would make use of existing VES capacity and permit much improved targeting of aquifer resource, more sustainable siting of boreholes and greater future resilience of Malawi's rural water-supply infrastructure.

Keywords: rural water supply; groundwater investigation; hydrogeophysics; aquifer; conceptual model; borehole; vertical electrical soundings (VESs); Malawi; Sustainable Development Goal 6

\section{Introduction}

Groundwater is the principal source of community drinking-water supply for Malawi's predominantly rural population. Our wider programme of research has recently mapped over 120,900 water points in Malawi, of which $49 \%$ are boreholes predominantly drilled to provide community hand-pumped water supply (Climate Justice Fund, mWater data 
retrieval, August 2020). Improving access to groundwater is pivotal to rural water supply across the developing world [1-3] and a priority means of enabling governments to meet Sustainable Development Goal (SDG) 6 targets [4]. Low borehole functionality rates, however, greatly hinder this ambition [5-7]. Although maintenance shortfalls, amongst other factors, are commonly blamed [8,9], these can obscure poor hydrogeological siting and borehole design that may primarily drive persistent functionality problems $[10,11]$. Boreholes screened in less permeable or saline units, or else drilled too shallow and vulnerable to dry-season dewatering or contamination may fail to respond to increased maintenance. They may become "Stranded Assets" [6]. Such circumstances could be alleviated with improved borehole siting informed by surface (hydro)geophysical methods.

Hydrogeophysics has long been invaluable to assessing complex aquifer settings throughout Sub-Saharan Africa [12,13]. Malawi's East African Rift System location causes its aquifers-primarily the fractured/weathered basement rock or valley alluvial aquifer systems - to be heterogeneous and discontinuous (faulted) with strong lateral and vertical lithological variation $[14,15]$. Siting of new boreholes in Malawi formally requires geophysical survey reconnaissance to assist decision-making on their location. The task is usually performed by the Ministry of Irrigation and Water Development (MoIWD or "the Ministry") or else Malawian or foreign contractors. One or a combination of the following ground-surface methods is used [16-19]: the 1-D resistivity method of vertical electrical sounding (VES), which provides vertical profiles of subsurface electrical resistivity; the 1-D conductivity method of electromagnetic profiling (EMP), which provides horizontal profiles of apparent subsurface electrical conductivity; and, the 1-D magnetic method of magnetic profiling (MP), which provides horizontal profiles of magnetic field intensity at surface. Such methods are, however, judged inadequate for the investigation of aquifer complexity typically expected in Malawi and indeed the wider African continent. VES, for instance, is only valid for subsurface configurations that are laterally invariant [20]. These are not prevalent in Malawi and not characteristic of fractured/weathered basement aquifer environments, nor alluvial aquifers where transmissive sands and gravel may prove laterally discrete $[14,15,21-23]$. Problems becomes obvious when comparing interpreted VES curves against "ground-truth" borehole drill-cutting logs where strong mismatches in lithology and depth are often observed [16,24,25].

Two-dimensional surface electrical resistivity tomography (2-D surface ERT) is an advanced geophysical method producing true cross-sections of subsurface electrical resistivity [26,27]. It is well-suited to the investigation of heterogeneous and discontinuous aquifers [28-32] and continues to be widely used [33-36]. However, ERT equipment is expensive. In more rapidly developing parts of the world, especially low- and middle-income countries (LMICs), access to such multi-channelled resistivity systems may be limited and 1-D VES may remain widely applied [37-41]. This is despite its largely inferior performance to ERT, but presumably reflects its success generally in physical aquifer and groundwater resource characterization [31,32,42-46]. ERT appears to have only been implemented in Malawi on a few one-off hydrogeophysical campaigns for borehole siting, all using foreign contractors [47]. Whilst the Ministry possesses (in 2019) an ERT unit and VES units and cables, it lacked expensive ERT cables and used the ERT unit only with VES cables for 1-D VES acquisition.

Although the VES method was designed to provide vertical 1-D profiles of resistivity $[19,20,23,31,32]$, a few recent studies have recognised that several VESs may be combined to provide pseudo or true cross-sections or volumes of subsurface resistivity and may provide an alternative option to surface ERT. For instance, studies have demonstrated several soundings may be inverted separately in 1-D, and the obtained vertical profiles of subsurface resistivity correlated to produce a pseudo cross-section of subsurface resistivity [48], or a pseudo volume of subsurface resistivity [49,50]. Such approaches require 1-D resistivity structures to be at the scale of the individual soundings, a condition apparently fulfilled in the study of Mohamaden and Ehab [48], but not in our earlier (alluvial aquifer) work in Malawi [49]. Our more recent work reported herein and implemented 
by Leborgne [51] utilises the recognition of Atzemoglou and Tsourlos [52] and Khalil and Monteiro Santos [53] that multiple soundings may be inverted together in 2-D, to obtain a true cross-section of subsurface resistivity. This approach requires that the soundings to overlap each other and to be fully collinear, as well as image 2-D resistivity structures. The method was suitably adapted for use in Malawi and wider developing world where resource may be limited to undertake true 2-D subsurface resistivity surveys. Its further potential to produce a true volume of subsurface resistivity from multiple, overlapping soundings inverted together in 3-D [54] is also noted for possible future extension. VES may also complement other geophysical techniques, for instance magnetic resonance sounding [55,56].

Our research goal was to improve hydrogeophysics and supply borehole siting in Malawi through adaptation for developing-country use and testing in Malawi of an advanced resistivity method in which multiple VESs are inverted together in 2-D, to obtain a true cross-section of subsurface resistivity. The methodology developed and described herein aimed to be as cost effective as possible, and be easy to use in a developing country context where VES capability is typically available enabling continued use (in Malawi at least) of existing equipment and knowhow. It also aimed to remove the need for reliance on expensive, possibly unaffordable ERT equipment to perform true 2-D subsurface resistivity surveys. This ambition was successfully realised and the developed VES technology demonstrated in four contrasting hydrogeological settings in Malawi. A hydrogeological conceptual model was developed for each of these settings, and the aquifer potential and, hence, preferred borehole siting location(s) were determined from the 2-D geophysical cross-sections obtained. This successful technology application has led to formative discussions with the Ministry on its deployment throughout Malawi that may allow enhanced delivery of rural water supply and support national attainment of SDG 6 targets.

\section{Materials and Methods}

\subsection{Study Setting}

Malawi is a small landlocked country with a population of 18 million people that is rapidly growing by around 3\% annually [57]. It is the most densely populated country in the Southern African Development Community (SADC) [58]. It had a national poverty rate in 2016 of $52 \%$ and extreme national poverty rate of $20 \%$ [59]. Over $80 \%$ of its population lives in rural areas and are mostly employed in subsistence farming. This study contributes to the Climate Justice Fund (CJF) Water Futures Programme of research, funded by the Scottish Government, that aims to assist the Government of Malawi in achieving SDG 6 (www.cjfwaterfuturesprogramme.com). CJF is led by the University of Strathclyde and provides local-to-national scale coverage across a broad range of water resource issues [5,6,60-62]. The field demonstration phase of this study was implemented within a CJF geographic focus area that covers most of the Traditional Authority (TA) of Mazengera located the Lilongwe District of Central Malawi (Figure 1).

TA Mazengara is a low-population, predominantly rural setting located in the plateau area of West Malawi. It comprises a pediplain (i.e., a series of gentle concave undulations) at over $1000 \mathrm{~m}$ a.s.l (above (mean) sea level) interrupted by smooth, short hills and by a few sharp, tall hills such as the hogs-back ridge of Chilenje Hill and the conical Nkhoma Hill reaching $1600 \mathrm{~m}$ a.s.1 [63] (Figure 1). Climate is of the Cwa type (temperate with dry winter and hot summer) in the Köppen-Geiger classification [64]. A warm, wet summer season lasts from November to April and a cool, dry winter season from May to October. Natural vegetation is savannah woodland, albeit now heavily cultivated. The plateau is dissected by numerous rivers, but without a significant standing body of water. Streamflow experiences marked seasonal variations, with many smaller rivers and streams dry during winter. Possible changes in some reaches may occur across the plateau from gaining to losing conditions where river flows become influent to groundwater $[14,15,60]$. Biological contamination (e.g., by faecal bacterium, Escherichia coli) of surface water is common. Accordingly, the rural population very heavily depends on groundwater extracted from 
boreholes or protected dug wells. Both are usually equipped with AfriDev hand pumps to provide safe drinking water and domestic supply.

(a)

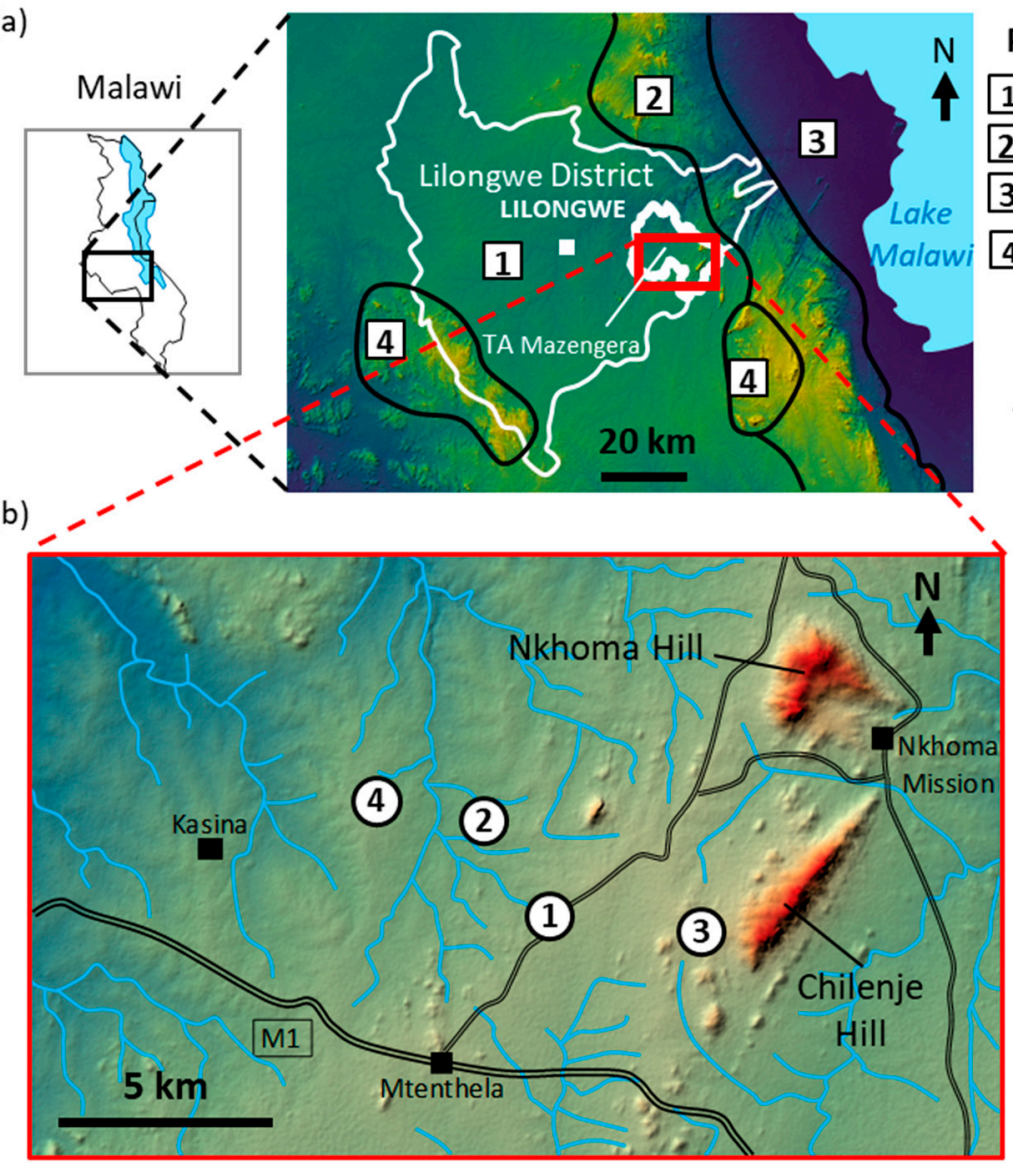

\section{Physiographic zones}

1 Plateau area

2 Rift valley escarpment

3 Rift valley plains

4 Highland areas

Elevation ( $\mathrm{m} \mathrm{AMSL}$ )
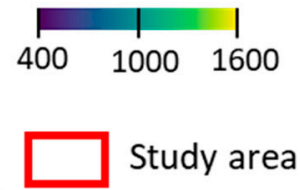

Elevation (m AMSL)

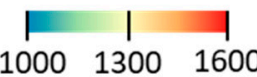

Resistivity surveys

(1) Malaza

(2) Msako

(3) Dete

(4) Muzongo

(c)

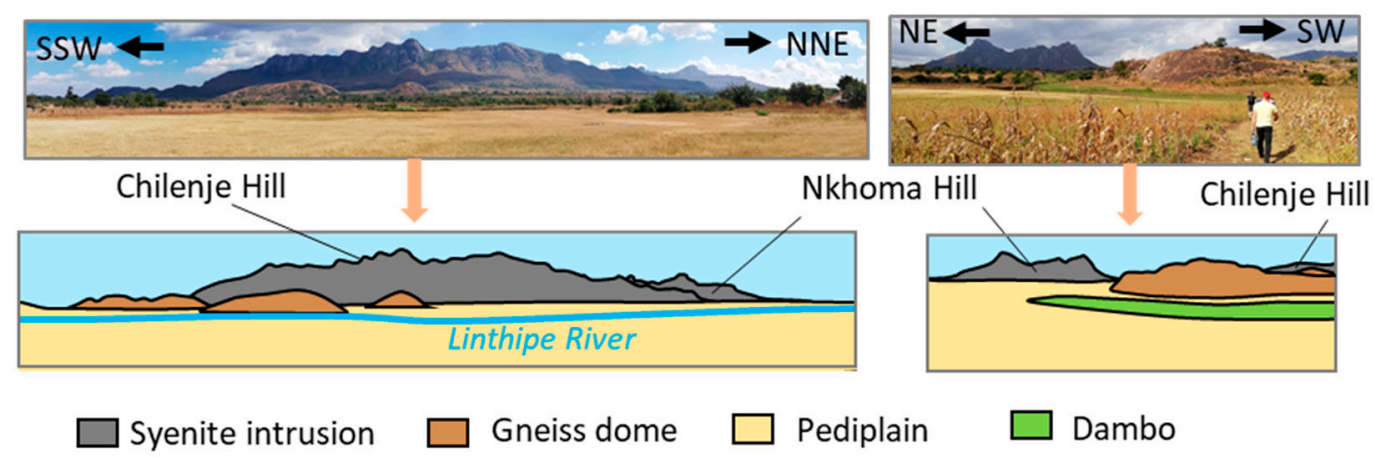

Figure 1. Study area setting: (a) surrounding physiographic setting (b) location of the four resistivity surveys and (c) landscape analyses in the study area. Topographic maps use Shuttle Radar Topography Mission (SRTM) Digital Elevation Model (DEM) data courtesy of NASA (Jet Propulsion Laboratory) and the US Geological Survey and were accessed via the Watkins [65] $30 \mathrm{~m}$ grid interface and plotted with QGIS 3.4.4.

\subsubsection{Geological and Hydrogeological Setting}

The study area is located in the extensive Proterozoic Basement Complex. Two main geological settings are distinguished in Malawi (Supplementary Materials Figure S1): zones where the Basement Complex is at surface, most of the study area; and zones where it is covered by colluvium or alluvium, occurring in the west of the study area [66] 
(Figure 2). Lithologies of the Basement Complex comprise: (i) medium- to high-grade metamorphic rocks (mainly felsic gneiss and granulites) which underwent foliation, folding, migmatisation and diapiric crustal flow, the latter being visible at the surface, in the form of short, soft hills corresponding to the outcropped portions of gneiss domes; and, (ii) syenite intrusions visible at surface as the tall, sharp hills of Nkhoma and Chilenje (Figure 1c) [14,15,63,66-68]. Metamorphic terrains of the Basement are attributed to tectonic and metamorphic activities of Proterozoic orogenies [69,70]. Strikes, foliations, elongated gneiss domes and lineaments display a general SSW-NNE orientation [66,68], but without obvious influence of the Early Miocene to Quaternary East African Rifting [68]. Four erosion surfaces were identified: Gondwana (Jurassic) and post-Gondwana (Early and Mid-Cretaceous) erosion surfaces, remnants of which could be the hills of Chilenje and Nkhoma; a Late Cretaceous to Early Miocene African erosion surface corresponding to the pediplanation responsible for the current general aspect of the plateau; and a later Miocene to Pliocene post-African erosion surface corresponding to the dissection of the plateau in the major river valleys $[63,71]$.

(a) Landsat RGB

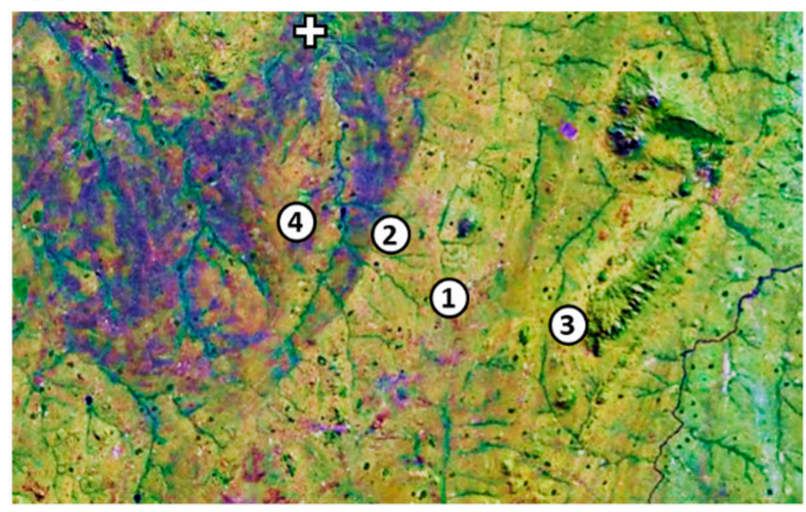

(b) Geology

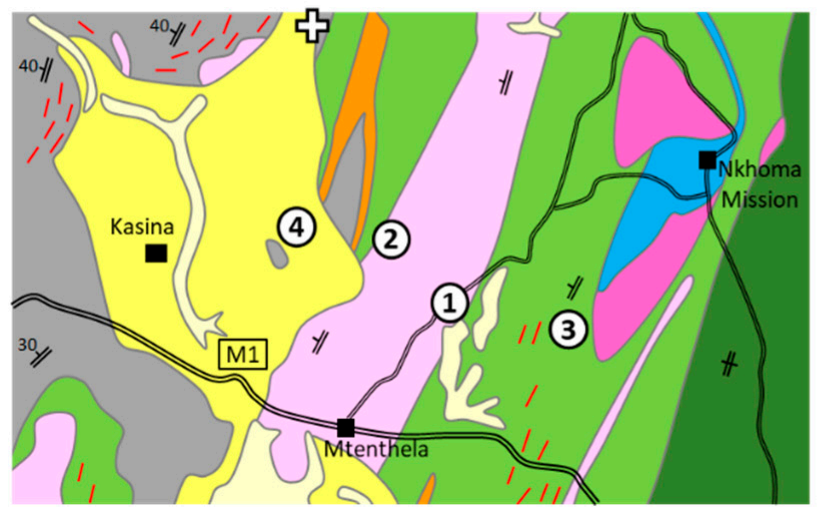

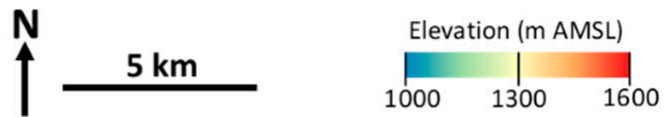

\section{TERTIARY-QUATERNARY SUPERFICAL DEPOSITS}

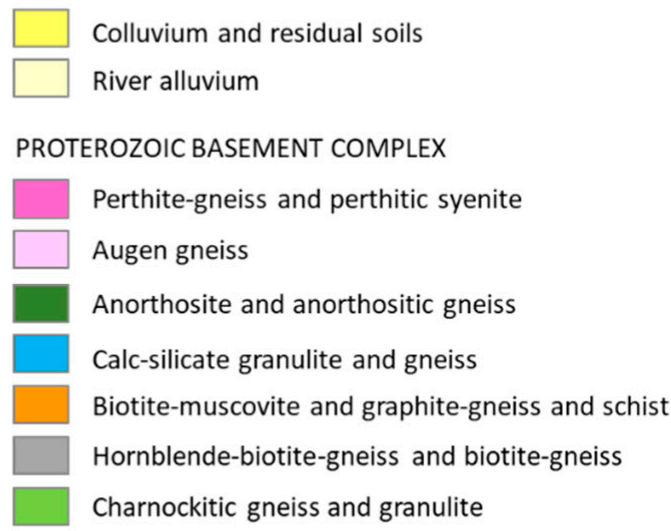

RESISTIVITY SURVEYS

OUTCROP ANALYSES

(1) Malaza

(2) Msako

(3) Dete

(4) Muzongo

Figure 2. Location of resistivity survey demonstration area shown relative to (a) Landsat image [72] and (b) the geological setting (digitized, adapted and reinterpreted from Hughes and Matumbi [66]). Landsat imagery courtesy of NASA Goddard Space Flight Center and US Geological Survey.

The Basement hosts aquifers that correspond to the classical concept of fractured/ weathered basement aquifers in tropical environments $[60,73]$. This concept was developed by, inter alia, Wright [12], Chilton and Foster [13], Carter and Bennett [67], Acworth [74], and Chilton and Smith-Carington [75]. These aquifers are defined by their association of an igneous or metamorphic fractured basement and a mantle of weathering products resulting from the prolonged, progressive, in situ chemical degradation of the basement rock into soil under tropical conditions. Detail of the typical vertical profile of fractured/weathered basement aquifers in tropical environments, assembling the above works, is conceptualized 
in Figure 3. This conceptualization underpins later hydrogeological conceptualisation madeof the geophysical cross-sections obtained. Division within Figure 3 is into the following units, from bottom to top $[12,13,74]$ : fresh unfractured and unweathered basement; fractured basement with shallow, sub-horizontal fracturing initiated by decompression accompanying exhumation of the basement and/or tectonic fracturing reaching deeper depths, of generally sub-vertical fractures often associated with lineaments (both types of fracturing may be enhanced by dissolution); saprock-mostly unweathered blocks detached from the parent bedrock in a matrix of crumbled bedrock of gravel/sand grain size; saprolite of progressive decrease in grain size upwards from gravel and sand to sand and clay; laterite comprising quartz grains, authigenic clays and $\mathrm{Fe}-\mathrm{Al}$ oxides/hydroxides are predominant. Variable topsoil covering (e.g., duricrust and latosol) depends on land use, cover and climate. Units may be grouped into super-units, such as the regolith (saprock, saprolite, laterite and topsoil) and the collapsed zone (laterite and topsoil), the thickness of which is usually c. $15-30 \mathrm{~m}$, exceptionally reaching $70 \mathrm{~m}$.

(a)

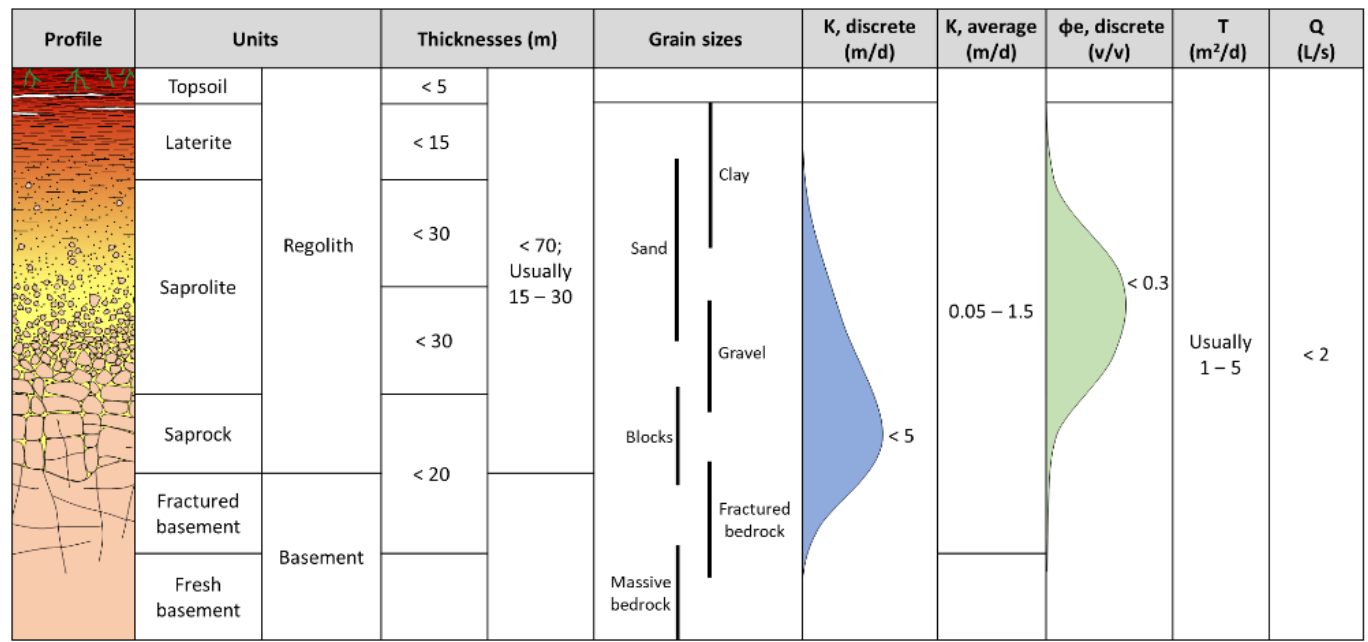

(b)

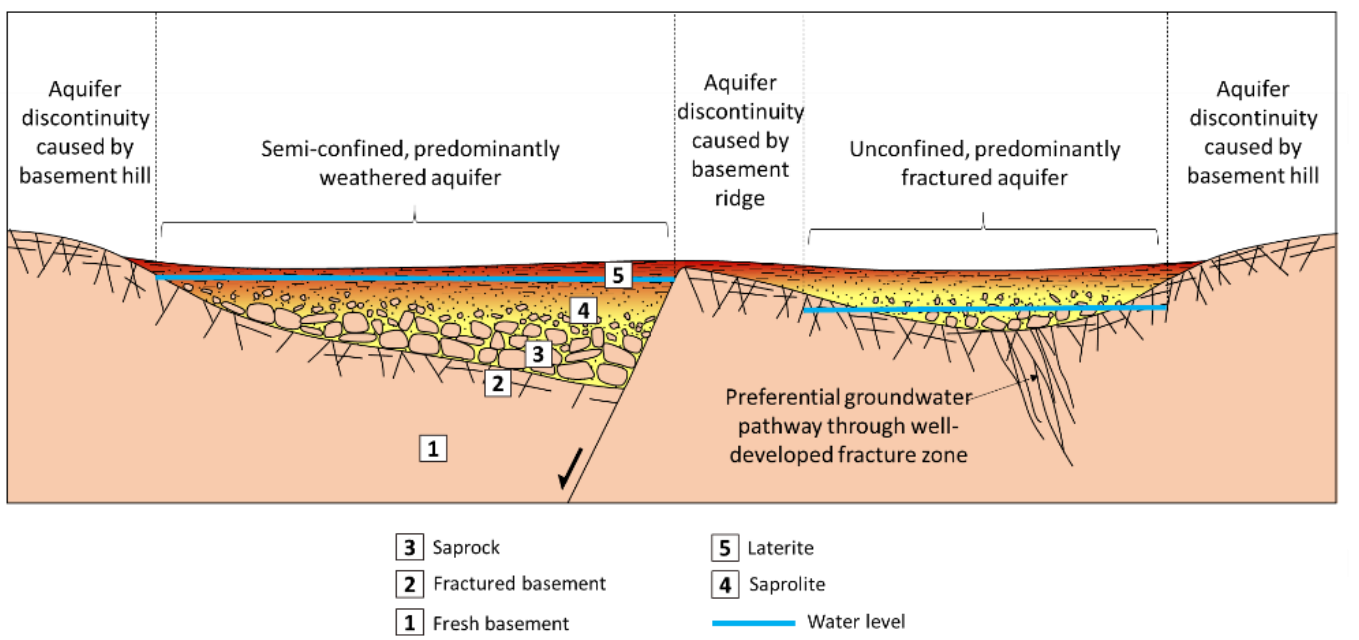

Figure 3. (a) Typical vertical profile of fractured/weathered basement aquifers in tropical environments. (b) Examples of aquifer subtypes among fractured/weathered basement aquifers in tropical environments.

Hydraulic conductivity $(K)$ and effective porosity $\left(\Phi_{e}\right)$ vary significantly over the profile (Figure 3). $K$ is usually highest, up to $5 \mathrm{~m} / \mathrm{d}$, in the fractured basement, saprock and gravelly, lower part of the saprolite; $\Phi_{e}$ is generally highest in the sandy (i.e., intermediate) part of the saprolite where it may reach up to $0.3 \mathrm{v} / \mathrm{v}$. The fractured basement and 
saprock provides most of the aquifer transmissivity and the saprolite much of the storage. Clayey parts of the saprolite/laterite may create semi-confined conditions with delayed yield. Transmissivity $(T)$ is typically only $1-5 \mathrm{~m}^{2} /$ day and borehole yield $(Q)$ may only exceptionally exceed $2 \mathrm{~L} / \mathrm{s}$. Aquifer productivity is, hence, low to moderate [12-14,74]. High lateral variations over short distances in terms of lithologies, deformation structures and water levels may give rise to several aquifer subtypes (Figure 3) [47]. Discontinuous aquifers restricted to troughs or occurrence parallel to strikes may be common [63]. Borehole capture zones are often limited due to the relatively low $K$ environment and decreasing, low hydraulic gradients at distance from escarpments [76] and may not be radially symmetric; for instance, fracture flows may be preferentially oriented. Despite their low to moderate productivities, the fractured/weathered basement aquifers of tropical Africa are widespread and occur at shallow depths, thereby providing a source of water that can be tapped widely at low exploitation costs. For these reasons, these aquifers are of major importance to the rural populations of tropical Africa, including Malawi [12,13].

In the west, a large area of the Basement Complex is covered by Tertiary and Quaternary colluvium [66], comprising eroded weathering products redistributed downslope of escarpments by gravity. Colluvium in tropical Africa may accumulate in depressions and form dambo [13] (Dambo a bantu word used in Malawi for "[ ... ] shallow linear depressions in the headward zone of rivers without a marked stream channel [, that] are seasonally waterlogged and grass-covered" [77]). Dambo are common throughout the study area and of particular hydrogeological interest due to their high water-retention capacity, providing a "buffer" dry-season water source [68].

Banda et al. [60], under our wider CJF programme, have recently provided a hyrochemical and stable isotope based hydrogeological conceptualisation of the wider Linthipe catchment draining into lake Malawi that encompasses TA Mazengara.

\subsection{Survey Methodology: Rationale and Approach}

The basis of the advanced resistivity method applied was to use multiple VESs that are inverted together in 2-D in order to obtain a true cross-section of subsurface resistivity. Perceived central to application in poorly resourced developing-country settings, such as Malawi, was the need for a method development that used low-cost VES equipment that removed the need for expensive ERT equipment to perform true 2-D subsurface resistivity surveys. Supporting processing software used should ideally be freeware.

Equipment preparatory works were undertaken in the UK, in advance of the relatively short period of opportunity for project fieldwork in Malawi [51]. This preparatory work enabled resistivity surveys to be configured in the field as a series of VESs, allowing true 2-D subsurface resistivity imaging. Each survey subsequently comprised the following: (i) selection of the survey site and survey preparation; (ii) acquisition of the survey as a series of VESs; (iii) survey data processing, to obtain a true cross-section of subsurface resistivity; (iv) interpretation of the subsurface resistivity cross-section, in terms of subsurface configuration; and (v) evaluation of the aquifer potential of the surveyed site from the subsurface configuration determined on the cross-section. Design of a methodology suited to the time-limited period of fieldwork available permitted development of a methodology that was time efficient for future practical application elsewhere and, hence, increased prospects of uptake. The component steps of the methodology developed are summarized below, with further details provided by Leborgne [51].

\subsection{Geophysical Survey Methods}

\subsubsection{Survey Configuration and Equipment Preparation}

A GF Instruments ARES I resistivity unit [78] (with 50 stainless-steel peg electrodes) owned by the University of Strathclyde was used for the study. Although it is an ERT unit with VES capabilities, it was used only in the study in VES mode. As it was not certain that the minimum requirement of three operators for conventional VES system implementation would always be met in Malawi, a multi-cable system was built, to allow acquisition 
of multiple individual resistivity measurements in a single electrode/cable layout by a single operator. Total cable length and, hence, component cost and equipment weight and volume were minimized by acquisition of two (rather than one) series of measurements per sounding.

A collinear 18-electrode array layout was used with a symmetrical cable arrangement of 9 single-conductor cables on either side of the sounding mid-point (electrodes and conductors numbered 1 to 9 and $1^{\prime}$ to $9^{\prime}$ on opposing sides). Two slightly different electrode layouts were used successively to acquire a "red series" and "green series" of individual resistivity measurements subsequently combined to give one sounding. A maximum electrode distance from the mid-point of $200 \mathrm{~m}$ was selected to provide a depth of investigation (DOI) of around $80 \mathrm{~m}$ with a Wenner, Schlumberger or Wenner-Schlumberger array [37]. Electrode distance from the mid-point was set to increase (quasi) exponentially, away from the mid-point, to allow for exponential decrease in resolution with depth: 0.78, $1.57,3.13,6.25,12.5,25,50,100$ and $200 \mathrm{~m}$ for the red layout; 0.39, 1.18, 2.35, 4.69, 9.38, $18.75,37.5,75$ and $150 \mathrm{~m}$ for the green layout (Figure 4). The cable system was built by the lead author, with the assistance of an electronics technician. Component cost for the cable system amounted to (GBP) $£ 350$, using average-quality components. Survey equipment photographs are provided in Figure 5, with further practical construction details of the cable system in the Supplementary Materials Box S1.
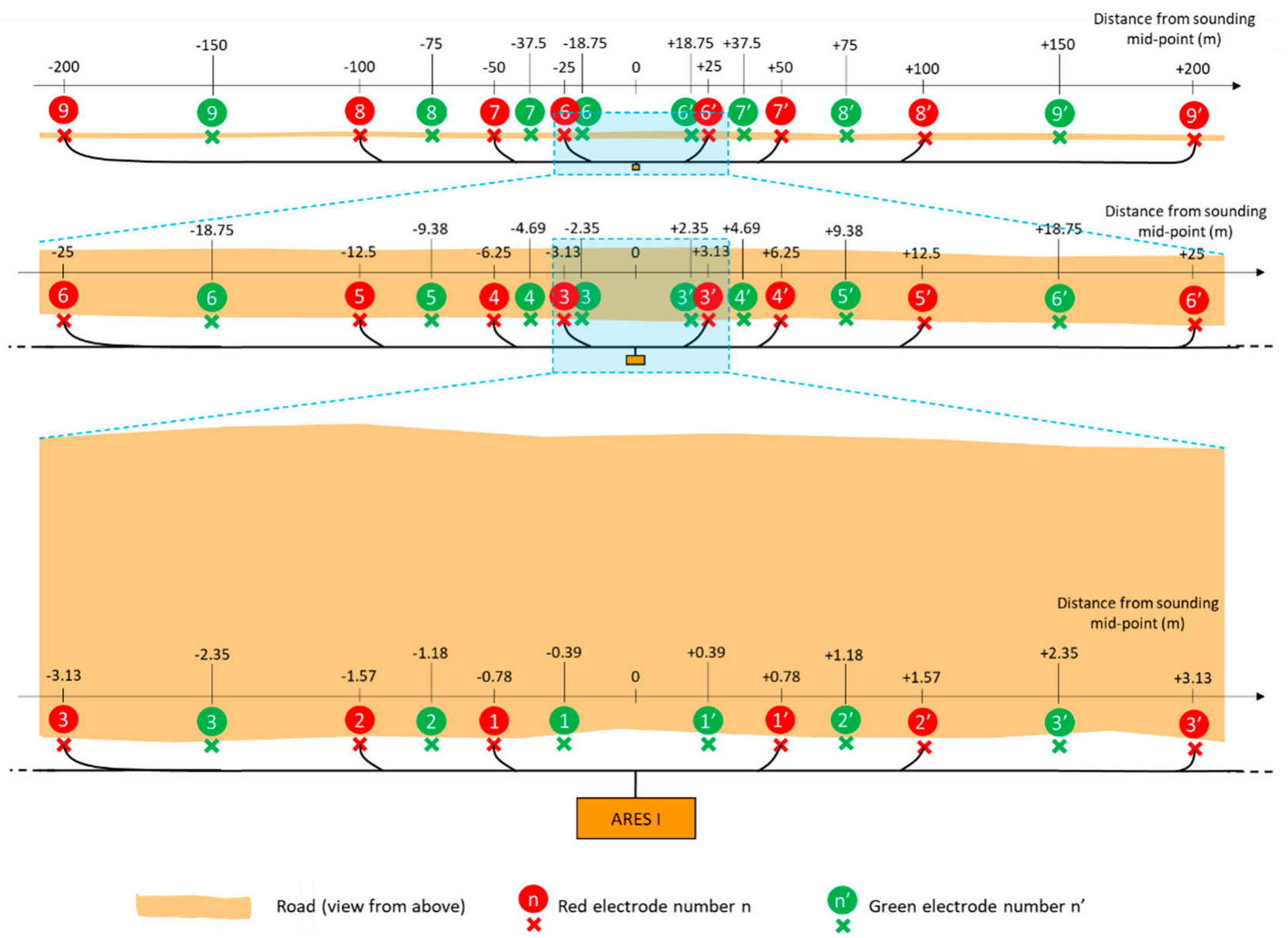

Figure 4. Electrode/cable layout designed for the individual vertical electrical soundings (VESs). 

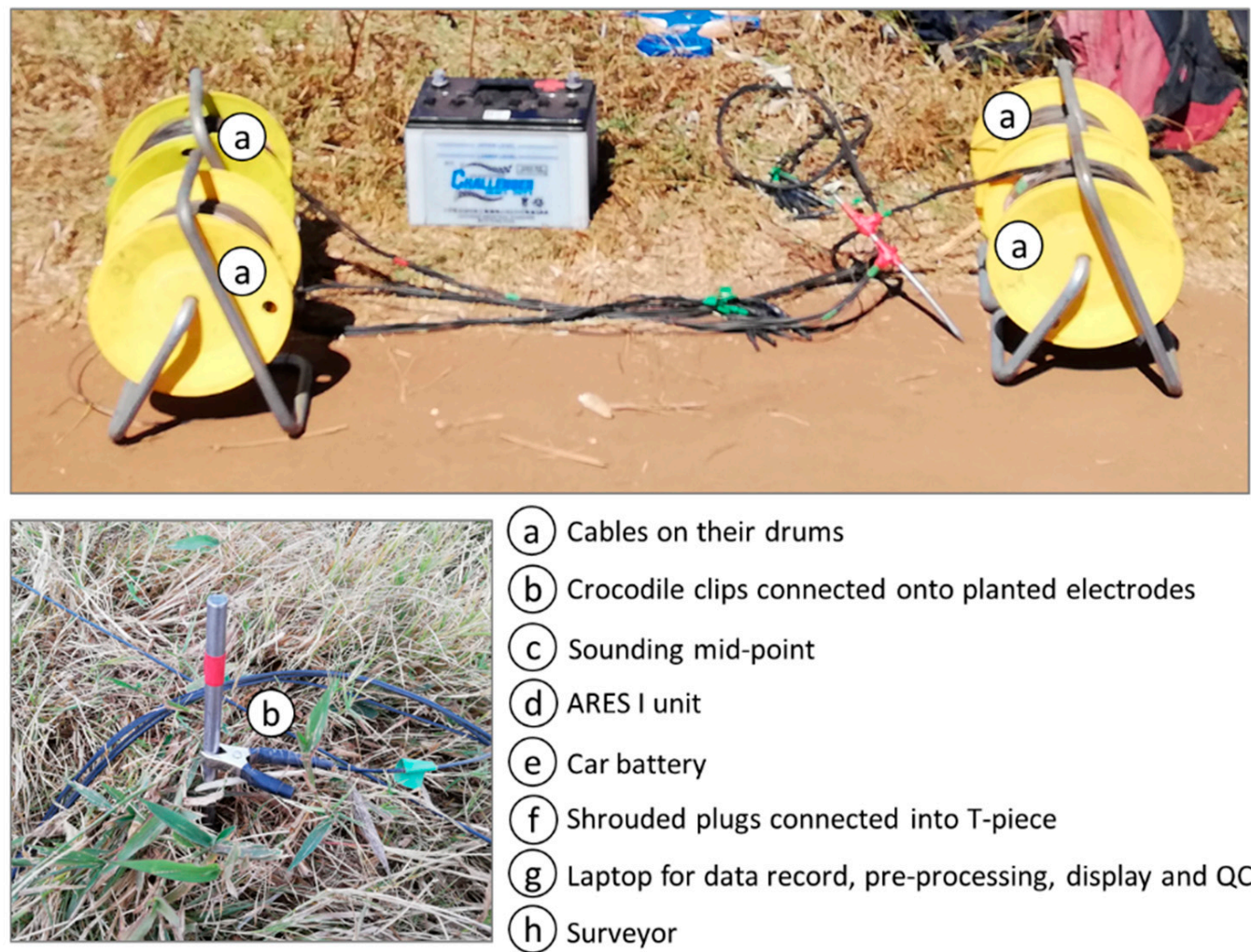

(a) Cables on their drums

(b) Crocodile clips connected onto planted electrodes

(c) Sounding mid-point

(d) ARES I unit

(e) Car battery

f Shrouded plugs connected into T-piece

g) Laptop for data record, pre-processing, display and QC

(h) Surveyor

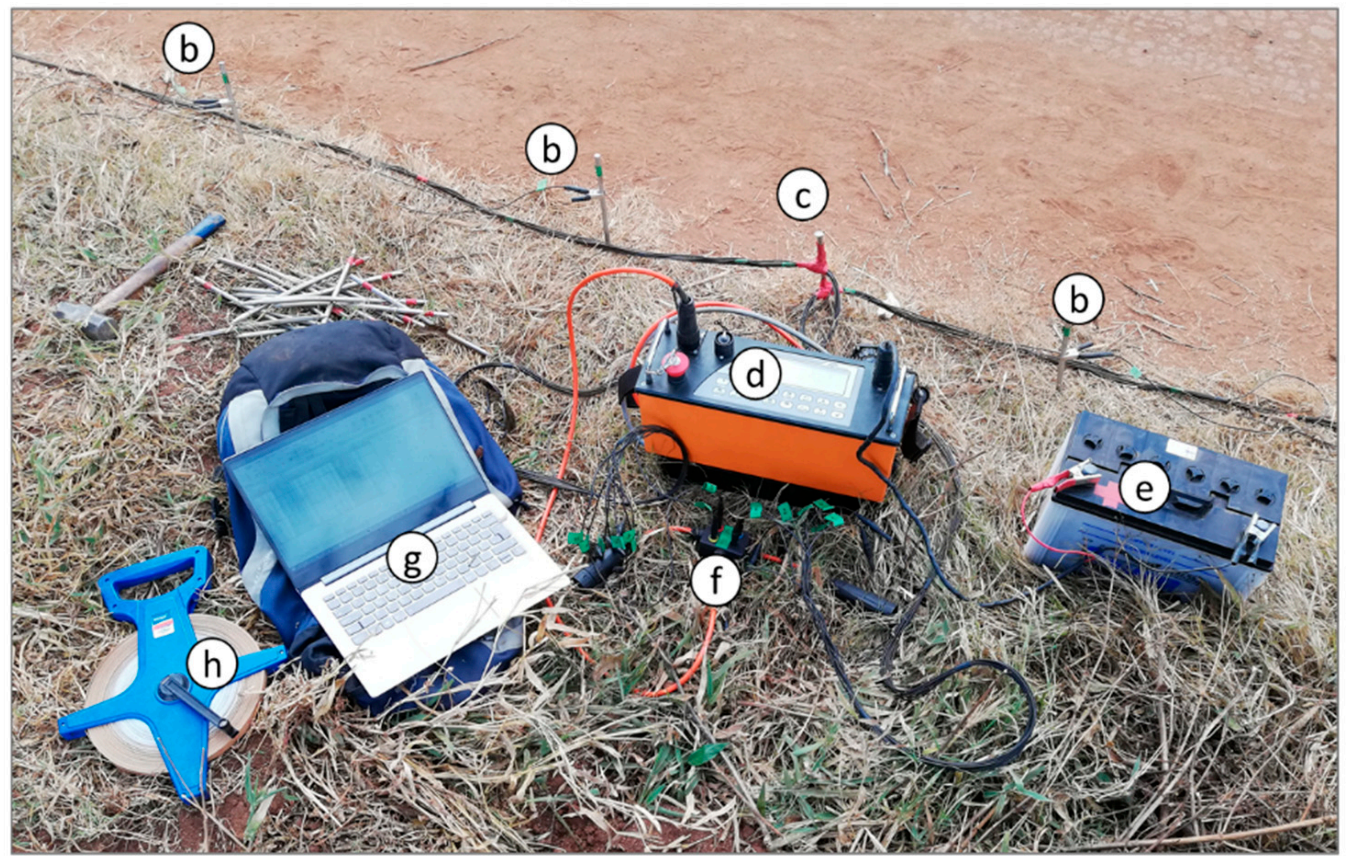

Figure 5. Photographs of the survey equipment.

\subsubsection{Measurement Acquisition}

Initially, measurements were to be acquired by using a single Wenner-Schlumberger array with $n=3.5$, and 12 individual resistivity measurements acquired per sounding ( 6 red and 6 green measurements) (where $n$ is the dipole separation factor). However, after the second survey, it was decided to acquire measurements by using two WennerSchlumberger arrays, one with $n=1.5$ and one with $n=3.5$, thereby doubling the number of individual resistivity measurements per sounding to 24 ( 12 red and 12 green measurements). To prevent adverse effects of electrode charge-up on data quality [79], the individual 
resistivity measurements were acquired in decreasing number of current electrodes. The sequence of electrode combinations designed for the acquisition of a red or green series of measurements with both Wenner-Schlumberger arrays is presented in Supplementary Materials Table S1.

Each 2-D survey was acquired as a series of 6 to 12 fully collinear soundings (electrodes on a same straight survey line at all times) with a $50 \mathrm{~m}$ spacing between the sounding midpoints (Supplementary materials Figure S2). This spacing allowed soundings to largely overlap each other, and this enable good lateral resolution in the true cross-sections to be obtained. Each individual resistivity measurement was acquired by using alternating positive/negative current pulses of $0.5 \mathrm{~s}$ duration each, with a targeted minimum voltage of $20 \mathrm{mV}$, and with 4 to 16 current pulses stacked to achieve a standard deviation of resistance (noted SD) below 1\% (the resistance is noted as $R$ and is calculated from the sent current, $I$, and the induced voltage, $U$, as $R=U / I)$. The general sequence of acquisition and the measurement parameter settings designed for the 2-D VES surveys are summarised in Supplementary Materials Figure S3.

\subsubsection{Survey Site Selection and Survey Preparation}

The survey sites were selected in varied geological and hydrogeological settings enabling method performance testing across a range of representative settings common in Malawi. Survey lines had to be perpendicular to lineaments and 2-D structures, such as lithological changes and hills. The sites had to be accessible by car and provide a line clear enough, sufficiently straight, long enough and that would not be crossed by traffic in order to install electrodes and cables. For a survey of $n$ soundings, the required line length is equal to $[50 \times(n-1)+400] \mathrm{m}$. Such lines could only be found in roadsides; however, roads had to be located outside villages, in order to avoid high road activity, to be sufficiently wide to allow a truck passing next to the cables and avoid crossroads. The rural location meant there were no buried pipes or cables to avoid. Moreover, water boreholes cased with PVC in the study area (now common across Malawi) meant surveys could be acquired adjacent to them.

Survey site preparation comprised a desk study and field reconnaissance characterisation, and setting up a specific acquisition plan that defined the survey layout (line location and orientation, number of soundings and sounding mid-point position). Site selection and survey preparation were interdependent and iterative processes, with site selection being guided and updated by the findings of the desk studies and field reconnaissance.

Desk studies and site selection were based on the analysis of $30 \mathrm{~m}$ SRTM DEM (Shuttle Radar Topography Mission Digital Elevation Model) NASA data [65] and of true colour satellite imagery [80] under free GIS software QGIS 3.4.4 [81], as well as on geomorphological, geological and hydrogeological findings made during an initial twoweek period of forensic surveying of community water point boreholes. Unfortunately, no borehole logs were available in the particular study area, as available boreholes were relatively old and drilled when record keeping was poor (recognising data availability is variable throughout Malawi but improving). Detailed national geological mapping and reporting in maps and memoirs by the Geological Survey of Malawi published in the 1960s-1970s remain a vital resource and were available for the study area and surroundings and consulted $[63,66,67]$. The only aquifer pumping test results available at a site accessible for resistivity surveying were from the Malaza well (again, availability of this data type is variable throughout Malawi). Field reconnaissance consisted of walkover surveys, geomorphological observations, quick outcrop analyses and asking village communities about the performance of their water points.

Although the above represents less than the ideal to "ground-truth" the geophysical profiles obtained, the information sourced is representative of the baseline of information often found throughout Malawi. 


\subsubsection{Survey Acquisition}

The surveys were acquired by the lead author, with field crews generally of three or four. Prior to acquiring any survey, village representatives were consulted for approval. The main hazards during survey acquisition consisted in electrocution by sent current, tripping on cables, hand injury when hammering pegs and back injury when lifting the heavy car battery. These hazards were addressed by using specific risk-assessment and control measures. Such measures included performing toolbox talks prior to acquisition, asking the villagers nearby to stay away from, and to not cross, the cables, and installing flags of safety tape on the cables for improved visibility.

Surveys were acquired by following the general sequence of acquisition and measurement parameter settings designed for all surveys, as well as the acquisition plans set up for each survey specifically. A laptop was used in the field to record, pre-process, display and quality-check, in real time, the acquired resistivity measurements. The values of sent current, induced voltage and resistance standard deviation were entered into a prepared Excel spreadsheet where apparent resistivities were automatically calculated and displayed for visual examination.

\subsubsection{Survey Processing}

The soundings for each survey were inverted together in 2-D to obtain a true crosssection of subsurface resistivity. Resistivity inversion was performed by using freeware R2 (v3.3), a forward/inverse solution for 2-D resistivity surveys developed by Binley [82]. $\mathrm{R} 2$ provides the option to use either a regular quadrilateral or a triangular mesh of finite elements (grid cells) to compute an inverted resistivity model. A quadrilateral mesh was used for which R2 only required the two following input text files to perform an inversion:

- Main input file R2.in, containing, inter alia, a definition of the quadrilateral mesh, a list of the electrodes with their positions, a surface-elevation profile to account for the topography; a definition of parameter blocks (i.e., zones of same inverted resistivity over neighbouring cells) and settings of inversion parameters (to calculate a sensitivity matrix);

- File protocol.dat listing all resistances recorded in the survey and their respective pairs of current electrodes and potential electrodes.

The contents of the R2 input files (e.g., definition of the quadrilateral mesh used, etc.) are provided in Supplementary Materials Table S2, together with Supplementary Materials Figure S4, which shows an example quadrilateral mesh used for the resistivity inversions. It took R2 between 10 and 20 min to complete an inversion and deliver output file f001_res.vkt containing both the inverted resistivity model and the sensitivity model.

\subsubsection{Survey Interpretation}

Freeware ParaView [83] was used to visualise the inversion results. In order to disregard regions of the subsurface that were poorly covered or sensed by the soundings, (i) the inverted resistivity models were displayed only up to $25 \mathrm{~m}$ beyond both outer sounding mid-axes, and (ii) the sensitivity model was displayed on top of the inverted resistivity model as a white shading increasing in opacity as sensitivities decrease. Progressive, continuous colour scales (linear or logarithmic (the latter shown)) were used for the resistivities, in order to avoid visualising sharp resistivity contrasts that may not exist.

The true cross-sections of subsurface resistivity thus obtained were interpreted in terms of subsurface configuration within the geological, hydrogeological and geomorphological context defined for the study area in general obtained from available geological maps or memoirs and for the survey sites specifically from local field inspection. Case studies from the literature of resistivity surveys of hydrogeological analogues were used for guidance, as deemed appropriate. Aquifer pumping test results only from the Malaza borehole-and, unfortunately, no borehole logs-were available at these particular survey sites, to support the geo-electric interpretations. 


\subsection{Evaluation of Aquifer Potential}

Based on the subsurface configurations determined on the subsurface resistivity crosssections, hydrogeological systems were defined, and their performance was predicted, to evaluate the aquifer potential of the surveyed sites, but also to highlight any uncertainties in the evaluation.

\subsection{Demonstration of Site Application}

Field resistivity surveys and other data acquisition were undertaken in Malawi over a seven-week period, from May to July in 2019. Surveys were conducted at four different sites of anticipated contrasting geological/geomorphological environments located in the TA Mazengara study area (Figure 2). The four sites approximately oriented along a SNW-NSE line cross-cutting and sampling different geological outcrops preferentially elongated along a SSW-NNE direction. The contextual detail for each site is presented within their respective result sections and site conceptual models developed. Geophysical survey datasets are provided in the Supplementary Materials (file: Geophysical survey field results).

\section{Results}

\subsection{Malaza Survey}

\subsubsection{Site and Survey Layout}

The Malaza survey site is located in a zone of the Basement Complex, where augen gneiss is the dominant lithology [66]. A major SW-NE-oriented road divides the site. Topography is flat, with a large dambo covering the area to the east of the road. No outcrop was observed. The Malaza borehole is located next to the road; it was drilled in 1961, and its yield was estimated at only $0.2 \mathrm{~L} / \mathrm{s}$ in the 1960s [63] (Figure 6a).

The survey line was laid along the east side of the road oriented SW-NE, i.e., roughly, but unfortunately parallel to most of the lineaments and 2-D structures (strikes, foliations and elongated gneiss domes) - this disadvantage was realised only after the survey had been acquired. Eight soundings were acquired, using only the Wenner-Schlumberger array with $n=3.5$. The Malaza borehole, only a few tens of meters away from the southernmost sounding mid-points, was rehabilitated and tested. However, testing failed due to a very low yield.

\subsubsection{Cross-Section}

The interpreted Malaza subsurface resistivity cross-section (Figure $6 \mathrm{~b}$ ) had a minimum sensitivity threshold of -3 applied corresponding to a DOI of c. $80 \mathrm{~m}$. Interpretation was simplified by a water level known to be very close to surface, $4.2 \mathrm{~m}$ below ground level (BGL), recorded at the Malaza borehole.

High resistivities up to $3 \mathrm{kOhm}$.m were observed below c. $30 \mathrm{~m}$ BGL, above which resistivity progressive decreased from a few $\mathrm{kOhm} . \mathrm{m}$ to 10 s of Ohm.m up to surface. The high resistivity zone was interpreted as a fresh basement and the overlying zone as a fracturing/weathering profile consisting of a succession upwards of fractured basement, saprock, saprolite, laterite and clayey dambo soil (Figure 3). Resolution was deemed insufficient to distinguish all the different units making up the fracturing/weathering profile. However, a distinction between clay-poor units (fractured basement, saprock and gravelly-sandy saprolite) and clay-rich units (clayey saprolite, laterite and dambo soil) was proposed, with a resistivity threshold of $100 \mathrm{Ohm}$.m separating both groups of units. Both the clay-poor and clay-rich units were found uninterrupted laterally and softly undulating. No deformation structures were identified on the cross-section. 
(a)
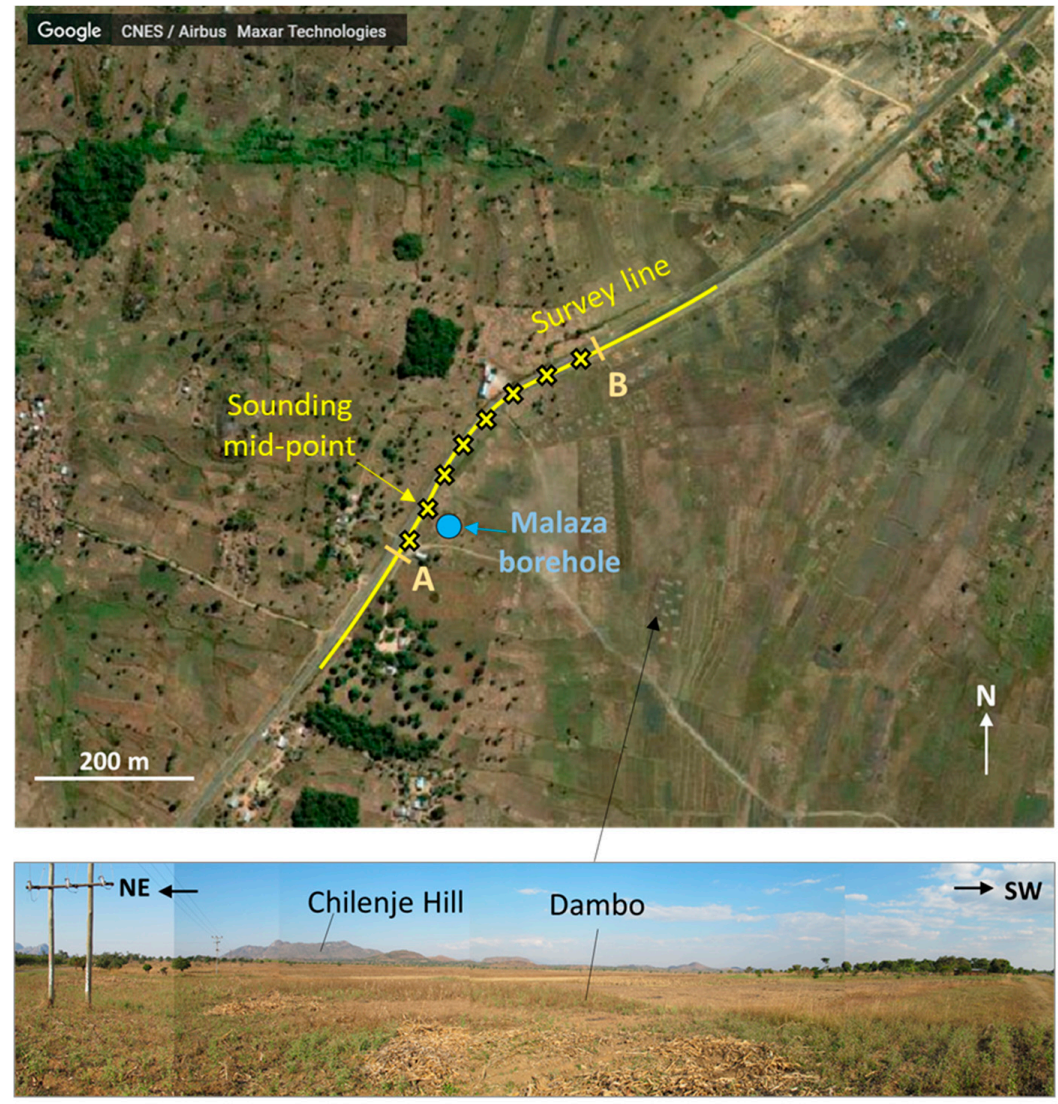

(b)

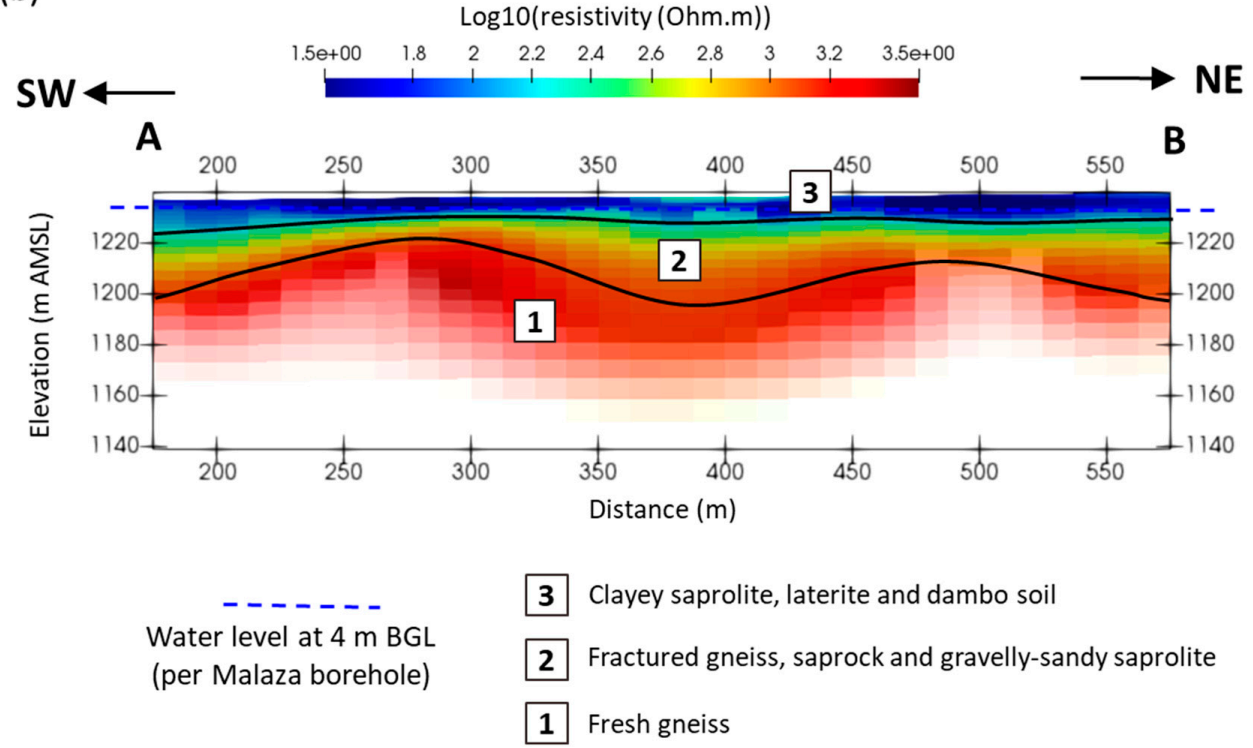

Figure 6. Malaza survey: (a) site survey line location (with individual sounding mid points marked as crosses) shown on a Google Earth satellite image (July 2020 download) of the area with accompanying landscape photograph; and, (b) interpreted subsurface resistivity cross-section obtain for section line AB marked on (a).

\subsubsection{Aquifer Potential}

Aquifer potential on the Malaza cross-section (Figure 6b) lies within the fractured basement, saprock and gravelly-sandy saprolite. Together, these have a total thickness varying between 10 and $30 \mathrm{~m}$, a value considered moderate for this type of aquifer. Borehole 
water-level occurrence within the clay-rich units of clayey saprolite, laterite and dambo soil indicates that groundwater is (semi-)confined. Undulations of the base of the fracturing/weathering profile, together with a drop of the water level, may cause geologically isolated, discontinuous groundwater bodies during the dry season. However, the presence of a dambo may allow some continued dry-season recharge. The very low yield recorded at Malaza may be explained by its unfavourable location close to where the fresh basement is highest and where the fractured basement, saprock and gravelly-sandy saprolite are thinnest.

\subsection{Msako Survey}

\subsubsection{Site and Survey Layout}

The Msako survey site west of Msako village is also located in a zone of the Basement Complex where augen gneiss is the dominant lithology [66] (Figure 7a). The landscape comprises a softly undulating plain interrupted in the East by small, soft, bare gneiss hills and many smaller gneiss outcrops. All gneiss outcrops are preferentially elongated along a SSW-NNE direction. Both of the two village boreholes have been abandoned due to very low yields. Village supply is now solely via a piping system importing groundwater abstracted several kilometres away.

The survey line was laid to the west of, and away from, the gneiss outcrops, along the south side of a WNW-ESE-oriented dirt road. The line was oriented perpendicular to the elongated gneiss outcrops, considered surface manifestations of 2-D structures at depth. Seven soundings were acquired by using only the Wenner-Schlumberger array with $n=3.5$. Two rivers are present at the site and were flowing when the survey was acquired (Figure 7a).

\subsubsection{Cross-Section}

The interpreted Msako subsurface resistivity cross-section (Figure 7b) had a minimum sensitivity threshold of -3 applied, corresponding to a DOI of $120 \mathrm{~m}$. A lowest possible water level was derived for the cross-section by interpolating the elevation profiles of the nearby flowing rivers, that were assumed to be gaining. This level was estimated at $10 \mathrm{~m}$ BGL for the whole cross-section.

A fracturing-weathering profile was identified with resistivities decreasing progressively upwards from a few kOhm.m to a few 10s of Ohm.m. Within this profile, it is proposed clay-poor units (fractured basement, saprock and gravelly-sandy saprolite) were distinguished from clay-rich units (clayey saprolite, laterite and topsoil) using a threshold of 100 Ohm.m. The fracturing-weathering profile was observed to have a fairly uneven base and to vary greatly in thickness from $30 \mathrm{~m}$ in the west to $5 \mathrm{~m}$ in the east. The clay-poor units were uninterrupted laterally but thinning out from $20 \mathrm{~m}$ in the west to a few metres in the east. The clay-rich units were laterally discontinuous, with a maximum thickness of $20 \mathrm{~m}$ in the West. Within the deeper basement, three conductive anomalies were observed elongated and dipping at c. $45^{\circ}$ (anomalies at $500 \mathrm{Ohm}$.m; rest of the deeper basement at $1-3 \mathrm{kOhm} . \mathrm{m}$, hence fresh basement). These conductive anomalies were interpreted as well-developed fault zones, rich in open, water-filled fractures, fault gouge or authigenic clays. Two uplifted basement blocks were identified between the faults interpreted as being inverse faults and indicative of a compressive tectonic regime. 
(a)
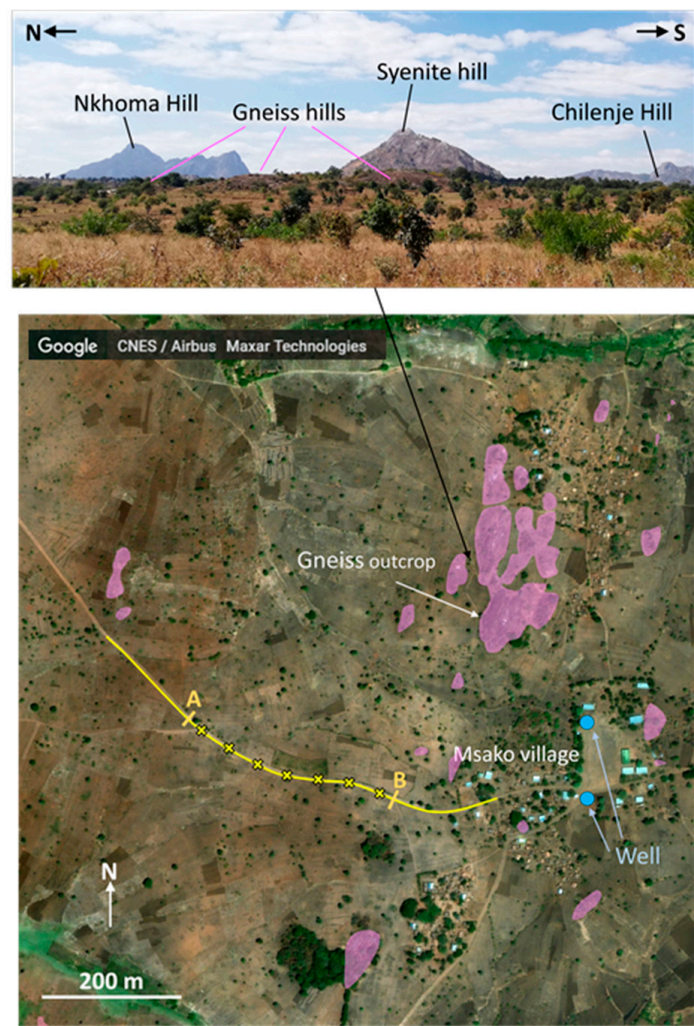

(b)

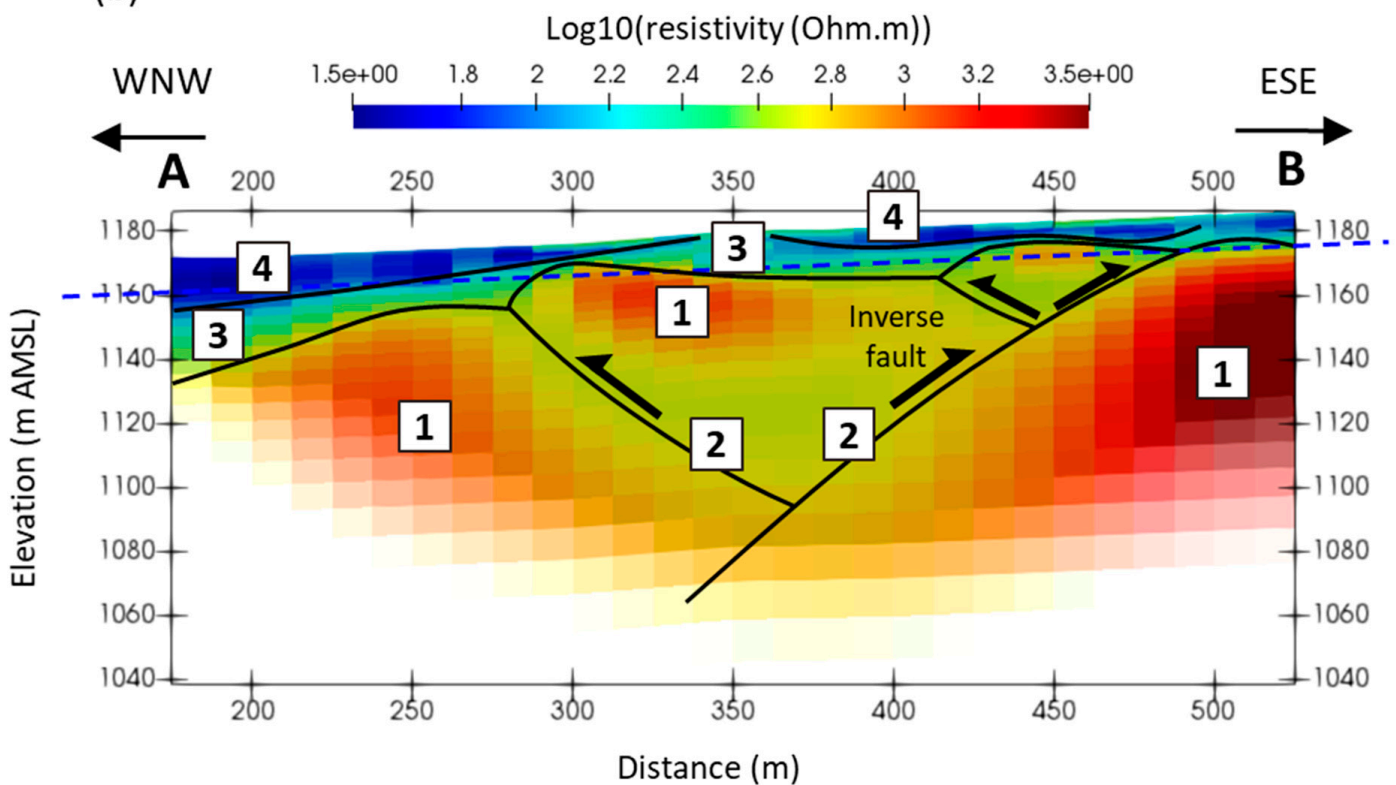

4 Clayey saprolite, laterite and topsoil

Deepest possible water level

3 Fractured gneiss, saprock, gravelly-sandy saprolite (extrapolated from flowing gaining rivers)

2 Fractured gneiss in well-developed fault zones

1 Fresh gneiss

Figure 7. Msako survey: (a) site survey line location (with individual sounding mid points marked as crosses) shown on a Google Earth satellite image (July 2020 download) of the area with accompanying landscape photograph; and, (b) interpreted subsurface resistivity cross-section obtain for section line $\mathrm{AB}$ marked on (a). 


\subsubsection{Aquifer Potential}

Aquifer potential on the Msako cross-section lies in two places: (i) the fractured basement, saprock and gravelly-sandy saprolite of the fracturing/weathering profile; and (ii) the fault zones (Figure $7 \mathrm{~b}$ ). Aquifer potential of the clay-poor units of the fracturingweathering profile appears rather limited, though, because of the generally modest thickness of these units. Both abandoned boreholes in Msako village were drilled among small outcrops of gneiss, illustrating the incapacity for a thin regolith to provide sufficient yields. Aquifer potential of the fault zones ranges from high to absent, depending on the material filling the open fractures. If the fractures are water-filled and well-connected, as may be typical, then the fault zones are likely to be transmissive with storage dependent on fracture density and aperture. Fractures filled with fault gouge or authigenic clays would present fault zones of negligible flow and storage capacity. The Msako cross-section is an example of how brittle deformation structures may provide additional aquifer potential to a basement.

\subsection{Dete Survey}

\subsubsection{Site and Survey Layout}

The Dete survey site is located in a zone of the Basement Complex, where charnockitic gneiss and granulite are the dominant lithologies [66] (Figure 8a). The site borders the southwest of Chilenje Hill and generally slopes westwards, decreasing in gradient from the foot of Chilenje Hill in the east to a plain in the west. This slope is interrupted by bare, soft, SSW-NNE-elongated gneiss and granulite hills that display exfoliation joints. Many boulders of gneiss and granulite can be observed at surface. Dete village lies in the east and Kabawo village in the west. Three boreholes are present in Dete: Dete 4 and Dete 6, which have been abandoned due to very low yields, and Dete 5, which is being used but also has a very low yield.

The survey line was laid along the north side of an E-W-oriented dirt road linking both villages of Dete and Kabawo, on a narrow roadside covered by dirt and grass. The survey line was, therefore, oriented roughly perpendicular to the elongated gneiss hills, considered surface manifestations of 2-D structures at depth. Eleven soundings were acquired by using both Wenner-Schlumberger arrays with $n=1.5$ and $n=3.5$ (Figure 8a).

\subsubsection{Cross-Section}

The interpreted Dete subsurface resistivity cross-section had a minimum sensitivity threshold of -4 applied, corresponding to a DOI of $120 \mathrm{~m}$-the minimum sensitivity was lowered, as compared to the previous cross-sections, in order to image the subsurface deeper (Figure 8b). In the absence of indications on the water level, the Dete cross-section was interpreted by assuming a water level a few meters below surface-this was the situation generally observed for the water levels in the study area surroundings during the water-point surveys.

Similar to the Malaza and Msako cross-sections, a fracturing/weathering profile (Figure 3) was also identified on the Dete cross-section. This profile appeared laterally continuous, with a thickness of 10 to $30 \mathrm{~m}$, but fairly disturbed. This disturbance was ascribed to the presence of boulders of gneiss and granulite at depth. Because of this heterogeneity, it was not possible to perform a valid distinction between the clay-poor and clay-rich units of the fracturing/weathering profile. While the deeper basement appears with resistivities of up to $3 \mathrm{kOhm} . \mathrm{m}$ on the Malaza and Msako cross-sections, it appears with resistivities of up to $30 \mathrm{kOhm} . \mathrm{m}$ on the Dete cross-section. Resistivities in excess of $3 \mathrm{kOhm} . \mathrm{m}$ on the Dete cross-section clearly define two shapes that are separated by a zone of lower resistivities from $500 \mathrm{Ohm} . \mathrm{m}$ to $3 \mathrm{kOhm} . \mathrm{m}$ : The two higher-resistivity shapes were identified as the cores of two gneiss domes, while the intermediate zone of lower resistivity was identified as the mantles of the gneiss domes. The base of the cores appeared constricted. The presence of higher resistivities in the core than in the mantle of the gneiss domes was explained by lithological differences between both regions of the 
domes, resulting, inter alia, from migmatisation that took place in the core when the domes were formed [84]. The upper half of both domes appeared to be missing, potentially as a result of erosion and weathering. The high-to-very-high resistivities recorded throughout the deeper basement were assumed to indicate an absence of open fractures in this zone. No deformation structures were identified on the cross-section.

(a)
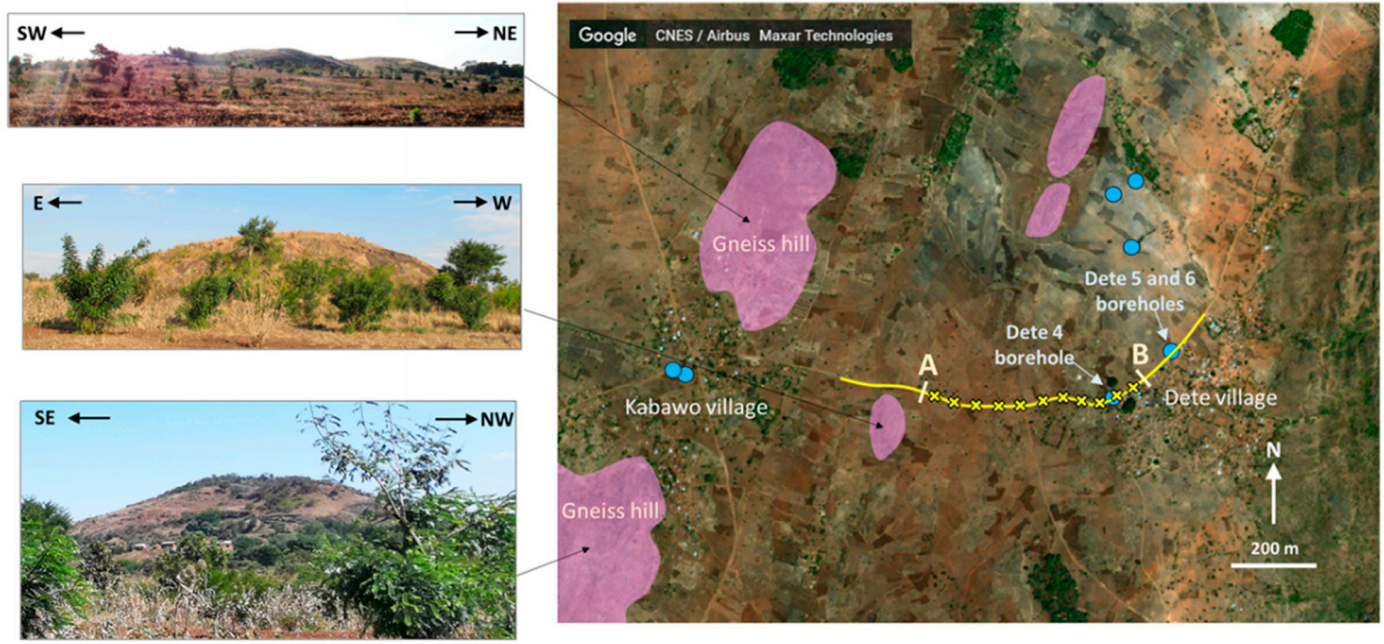

(b)

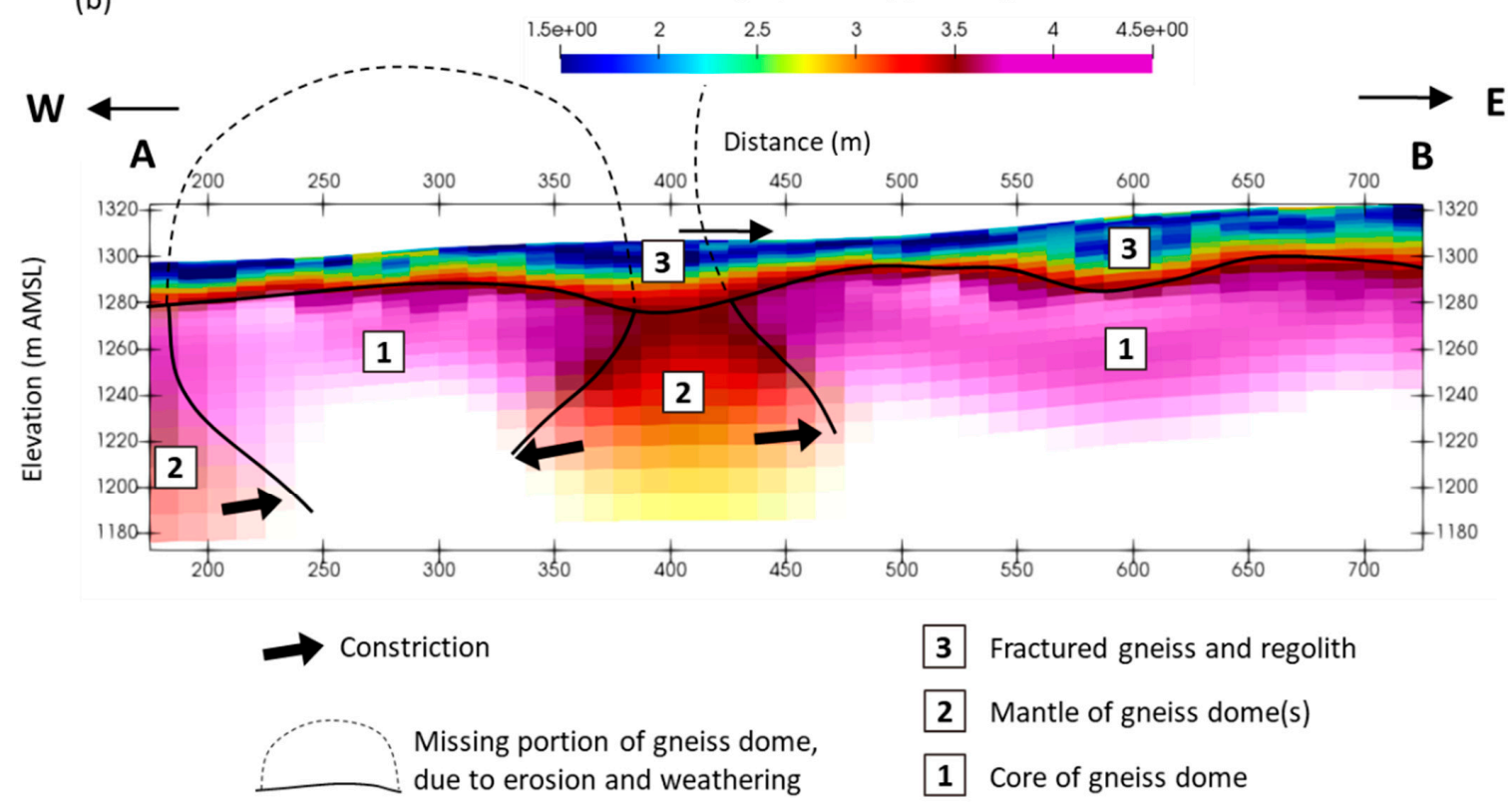

Figure 8. Dete survey: (a) site survey line location (with individual sounding mid-points marked as crosses) shown on a Google Earth satellite image (July 2020 download) of the area with accompanying landscape photographs; and (b) interpreted subsurface resistivity cross-section obtain for section line AB marked on (a).

\subsubsection{Aquifer Potential}

Aquifer potential on the Dete cross-section lies within the clay-poor units of the fracturing/weathering profile (Figure $8 \mathrm{~b}$ ). These units could not be clearly identified, due to the disturbance caused on the resistivity image by boulders. However, the very low yield of borehole Dete 4, located on the cross-section, suggests a very low aquifer potential for these units and accords with the clay-rich lithologies observed. 


\subsection{Muzongo Survey \\ 3.4.1. Site and Survey Layout}

The Muzongo survey site is located in a zone indicated as Tertiary-to-Quaternary colluvium by Hughes and Matumbi [66] (Figure 9a). The site surface gently slopes towards the east, and outcrops are absent. The Muzongo village lies in the east. The survey line was laid along the north side of a WSW-ENE-oriented dirt road west of Muzongo, on a narrow roadside covered by dirt and grass. Twelve soundings were acquired by using both Wenner-Schlumberger arrays with $n=1.5$ and $n=3.5$.

(a)

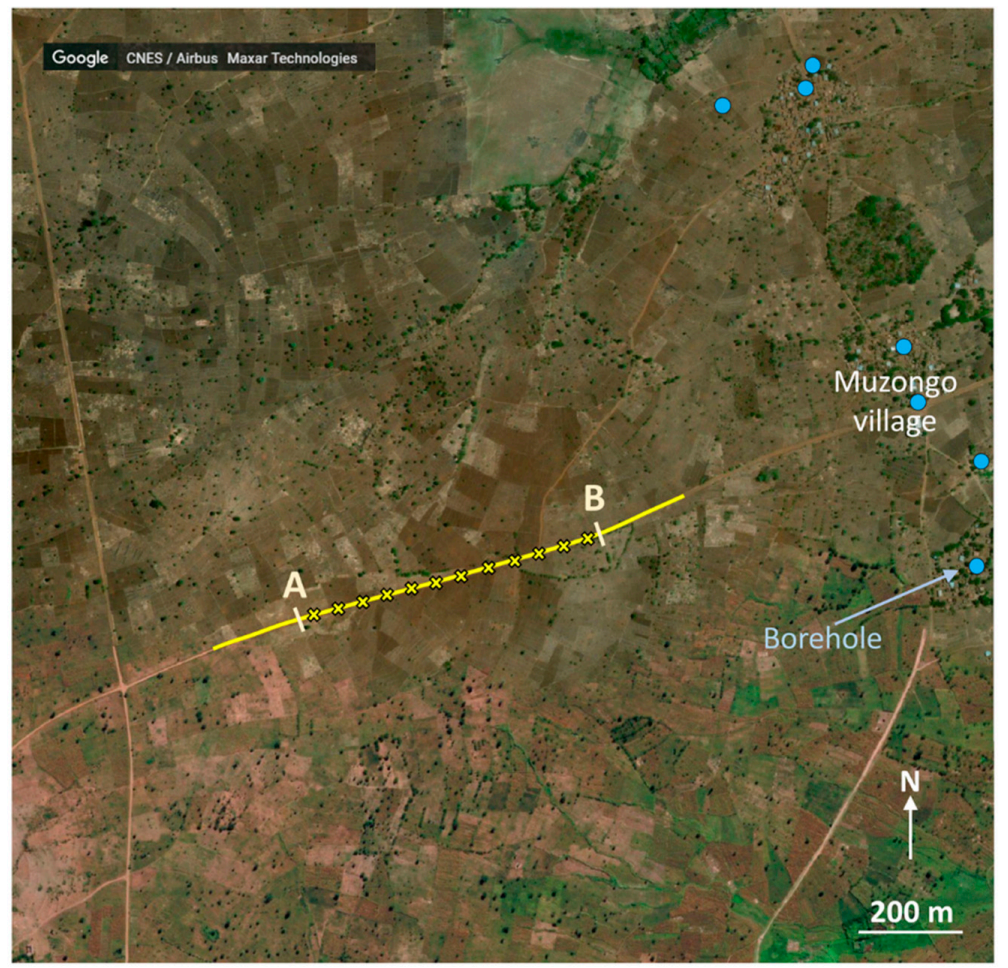

(b)

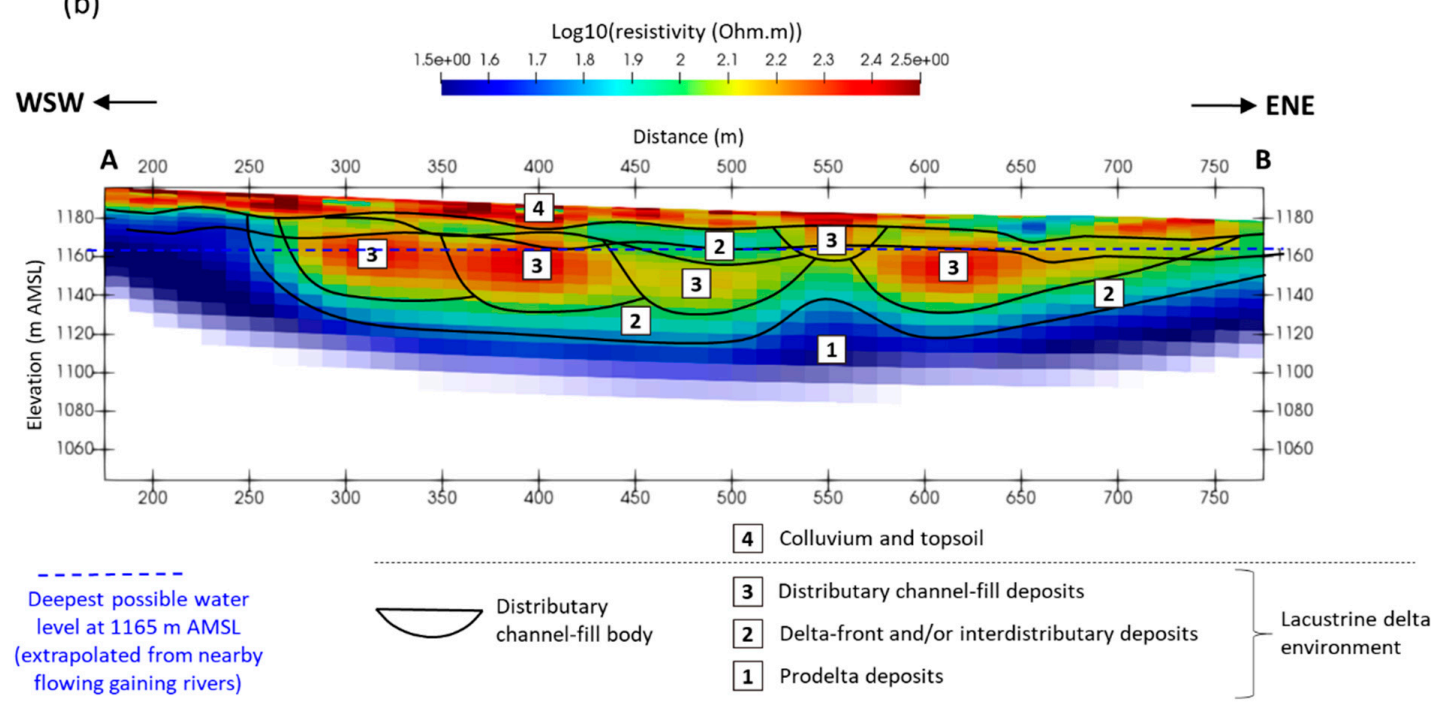

Figure 9. Muzongo survey: (a) site survey line location (with individual sounding mid points marked as crosses) shown on a Google Earth satellite image (July 2020 download) of the area; and, (b) interpreted subsurface resistivity cross-section obtain for section line AB marked on (a) (interpretation includes consideration of outcrop analysis (Figure 10)). 


\subsubsection{Cross-Section}

The interpreted Muzongo subsurface resistivity cross-section had a minimum sensitivity threshold of -3 applied, corresponding to a maximum DOI of $100 \mathrm{~m}$ (Figure S5 (preliminary interpretation); Figure $9 \mathrm{~b}$ (final interpretation)). A lowest-possible water level was derived for the cross-section by interpolating the elevation profiles of the nearby flowing rivers that were assumed to be gaining. This level was estimated between 30 and $15 \mathrm{~m}$ BGL. However, the water level was most likely significantly closer to surface, since the site surface is tens of meters higher than the nearby rivers.

The following elements were distinguished on the cross-section (Supplementary Materials Figure S5): a $10 \mathrm{~m}$ thick superficial zone of high resistivities (150 to $300 \mathrm{Ohm} . \mathrm{m}$ ) and, deeper, five laterally elongated resistive bodies (100 to $250 \mathrm{Ohm} . \mathrm{m}$ ) surrounded by a conductive background ( 30 to $50 \mathrm{Ohm} . \mathrm{m}$ ). The shapes of the deep resistive bodies were clearly identified as those of channel-fill bodies intersected transversally by the crosssection. Lateral amalgamation was noticed between the channel-fill bodies, which, together, appeared to form a broad channel-fill complex. This geometry was interpreted as being the result of lateral migration or switching of the active channel(s) through time. The high resistivities of the channel-fill bodies were interpreted as being those of coarse clay-poor deposits, likely made of sand or sandstone. The conductive background was interpreted as clay-rich sedimentary deposits, likely made of mudstone. The resistive superficial zone was interpreted as dry colluvium and topsoil. It is likely that the water level of the channel-fill bodies lies in the upper part of the clay-rich sedimentary deposits, but that the latter retain significant levels of moisture above the water level due to strong capillary forces, and that, therefore, the lower limit of the resistive superficial zone corresponds to both a change in lithology and moisture level.

\subsubsection{Outcrop Analysis}

In order to obtain more information on the sedimentology of the area, two large outcrops exposed by the erosion of a meandering river were analysed near Chiluwe village, in the northeast of the zone that is indicated as Tertiary-Quaternary superficial deposits by Hughes and Matumbi [66] (Figures 2b and 10a).

Outcrop 1 consists of debris-flow deposits separated by clayey layers (Figure 10b). The debrites are massive, with continuous thicknesses of up to $10 \mathrm{~m}$, and comprise a matrix-supported structureless breccia of angular, pebble- to boulder-size gneiss clasts in a coarse to very coarse angular sandstone matrix of the same mineralogical composition as the gneiss clasts (quartz, felspars and hornblende). The clayey layers are thin ( $\mathrm{cm}$ scale) and consist of grey-blue claystones containing stromatolites and accumulations of bivalve shell clasts. The clayey layers separate successive debris-flow units that display erosive bases. The deposits were interpreted as being those of alluvial fans that developed at the foot of gneiss hills and that were, at least partially, immersed in a lake.

Outcrop 2 consists of a succession upwards of thinly bedded deposits, channel-fill deposits and debris-flow deposits (Figure 10c). The thinly bedded deposits are found at the base of the outcrop over $5 \mathrm{~m}$ and comprise thin ( $\mathrm{cm}$ scale) alternating beds of medium sandstones and mudstones. The thinly bedded deposits were found slumped at places where they display convolutes. The channel-fill deposits were found above the thinly bedded deposits, are over $5 \mathrm{~m}$ and are made of medium to very coarse angular sandstones. The channel-fill deposits are organised as small individual channel-fill units (maximum $1 \mathrm{~m}$ thickness) with erosive bases; together, these units form a channel-fill body. The debris-flow deposits are found on top of the channel-fill deposits, are over $1 \mathrm{~m}$ and display the same textures and mineralogy as the debris-flow deposits observed on Outcrop 1. The deposits of Outcrop 2 were interpreted as being those of three sedimentary environments: (i) the thinly bedded deposits being those of lacustrine turbidite fans; (ii) the channel-fill deposits being those of lacustrine deltas; and (iii) the debris-flow deposits being those of alluvial fans that developed at the foot of gneiss hills and that were, at least partially, immersed in a lake. 
(a) General view

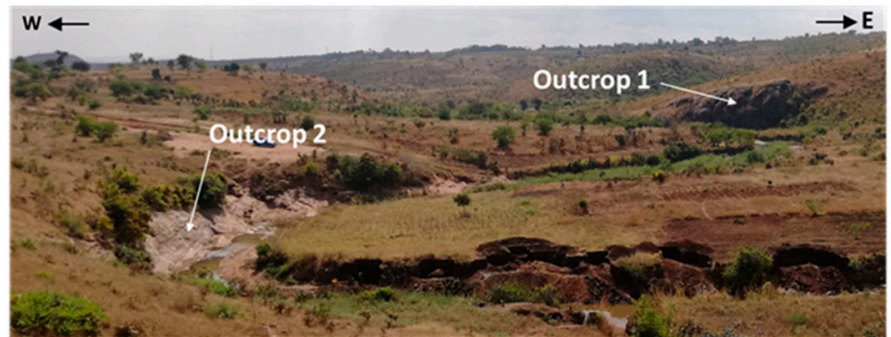

(b) Outcrop 1 analysis

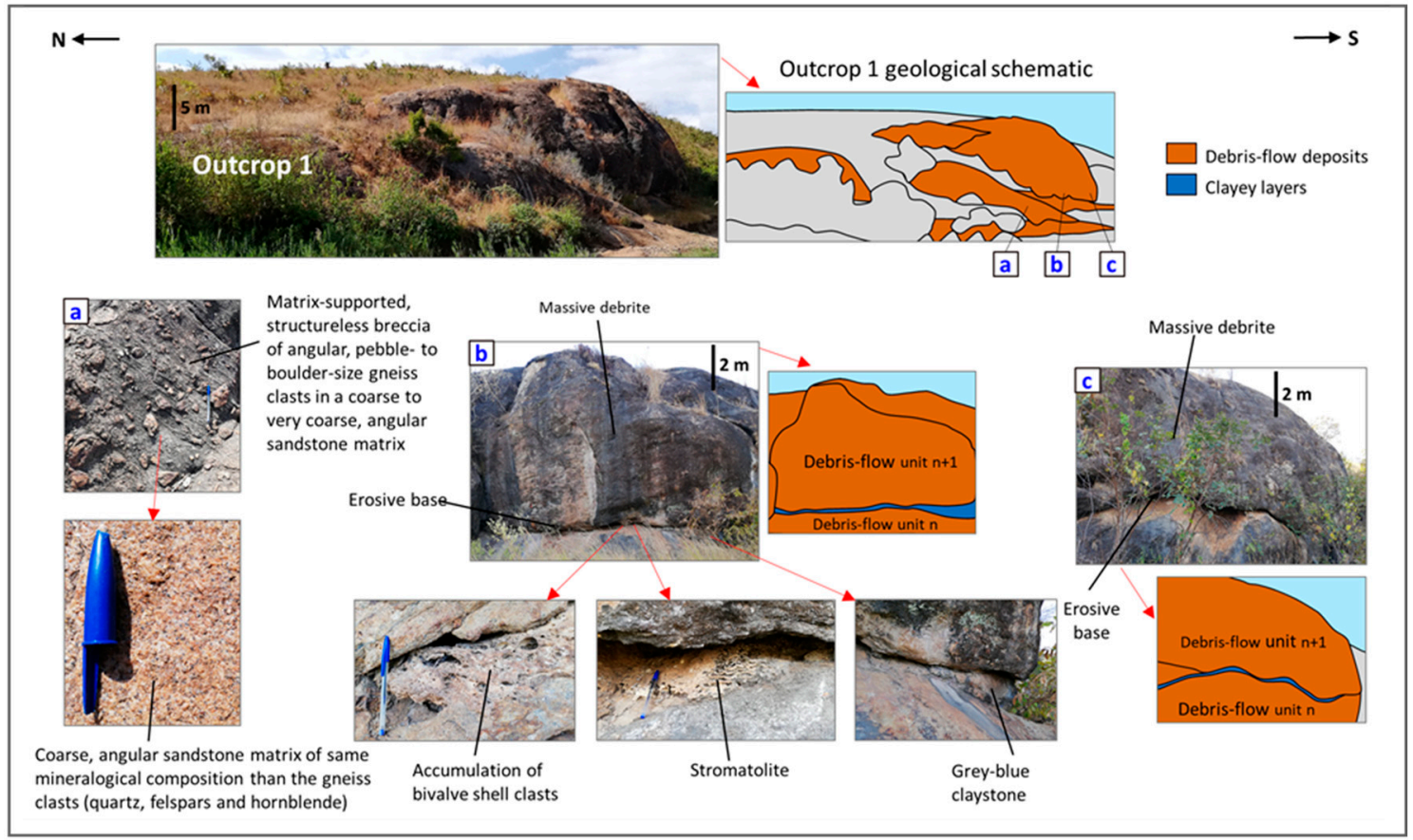

(c) Outcrop 2 analysis

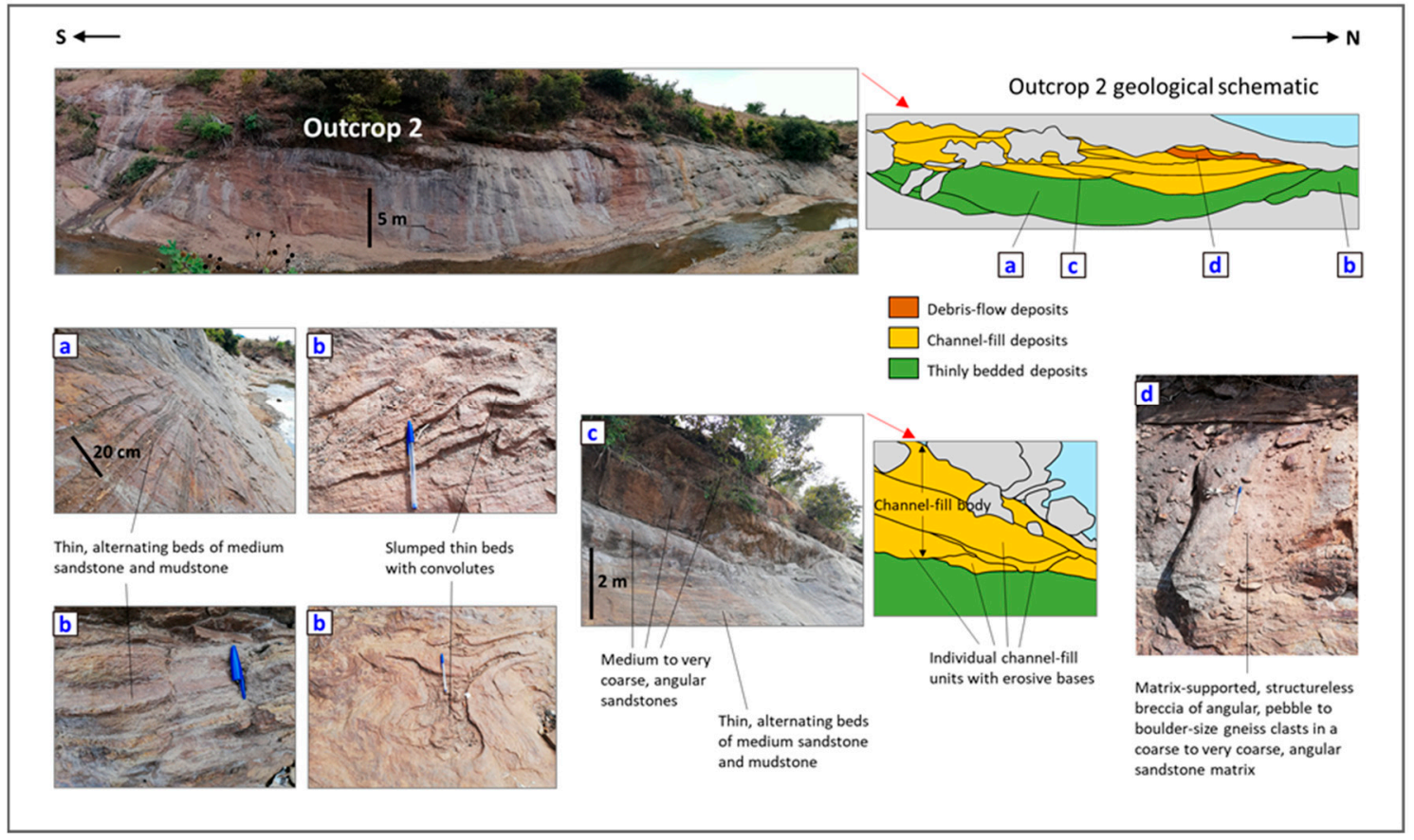

Figure 10. Chiluwe outcrop analyses: (a) general view of outcrops, (b) Outcrop 1 analysis and (c) Outcrop 2 analysis. The locations of letter-labelled photo are marked on the geological schematic of the main outcrop photo. 
An association of sedimentary environments was proposed that explains the observations made on the Chiluwe outcrops (Supplementary Materials Figure S6). This association comprises alluvial fans, deltas, turbidite fans and a basin floor that developed in this order from gneiss hills (the source of the sediments) into a paleo-lake. Progradation and retrogradation events are generally quick in lacustrine environments, since lake levels are usually unstable on sedimentary timescales. The environmental succession turbidite fan/delta/alluvial fan identified upwards on Outcrop 2 was interpreted as indicating an evolution with time towards more proximal environments, hence, a progradation.

In the light of these sedimentological findings, the interpretation of the Muzongo subsurface resistivity cross-section was revised (Figure 9b): (i) The channel-fill deposits were interpreted as deltaic distributary channel-fill deposits made of sandstones; (ii) the clayrich deposits surrounding the channel-fill bodies were divided between inter-distributary and/or delta-front deposits made of clayey siltstones (more resistive and in contact with the channel-fill bodies) and prodelta deposits made of silty claystones (more conductive and further away from the channel-fill bodies); and (iii) the deltaic environment was assumed to have developed within a lake.

\subsubsection{Aquifer Potential}

Aquifer potential on the Muzongo cross-section lies within the sandstones of the deltaic distributary channel-fill deposits and ranges from high to absent, depending on the extent, petrophysical quality and connectivity of these sandstones (Figure 9b). The sandstones are expected to extend perpendicular to the cross-section, along the longitudinal axis of the channel-fill bodies. The porosity and permeability of sandstones are usually primarily controlled by diagenetic processes such as cementation and by fracturing. It is impossible to estimate these properties of the sandstones from the cross-section. However, the channel-fill sandstones of Outcrop 2 appear well consolidated and insignificantly fractured, suggesting moderate petrophysical quality at best. Connectivity of the sandstones may be permitted by sandstone amalgamation at two scales: amalgamation of the channel-fill bodies and amalgamation of the channel-fill units within the channel-fill bodies. The channel-fill bodies appear well amalgamated on the cross-section, forming a broad channel-fill complex. The channel-fill units within the channel-fill bodies are not resolved on the cross-section. However, sand-on-sand contact appears to be prevalent between the channel-fill units of Outcrop 2.

\section{Discussion}

\subsection{Method Performance}

\subsubsection{Imaging Performance}

Imaging performance of the resistivity method implemented is comparable to that of 2-D surface ERT. Detailed subsurface resistivity cross-sections were successfully obtained, on which a wide range of (hydro)geological features were identified with high levels of certainty: (i) fresh basements; (ii) fracturing-weathering profiles, within which clay-poor units (fractured basement, saprock and gravelly-sandy saprolite) could be distinguished from clay-rich units (clayey saprolite, laterite and topsoil); (iii) buried gneiss domes, with a distinction made between core and mantle; (iv) well-developed fault zones, with a determination of the movements of the fault blocks; (v) colluvium; and (vi) deltaic deposits (prodelta, delta front, distributary channel-fill and interdistributary deposits). Resolving this range of features together with general understanding of a specific feature's expected hydrogeological significance (i.e., probable groundwater flow and storage capacities) permits a 2-D cross-sectional characterisation of aquifer potential. Knowledge of the surrounding 3-D geological structure expected permits extrapolation of the aquifer potential into three dimensions, at least locally.

DOI was in the range of $100 \mathrm{~m}$ for all cross-sections with fair minimum sensitivity thresholds for data display. Such DOI is significantly deeper than boreholes equipped with Afridev handpumps, often drilled to around $50 \mathrm{~m}$ depth in Malawi [62]. Moreover, it is 
deeper than most fractured/weathered basement aquifers in tropical environments. Hence, survey characterization covers the depths of predominant interest for assessing aquifer potential typically drilled, but also would allow investigation of Malawi's largely untapped deeper groundwater resources at $>50-100 \mathrm{~m}$ depths, especially some of the thicker alluvial aquifer units in, for instance, the Shire River Basin [14,61].

Although not attempted in this study, both vertical and horizontal resolutions of the cross-sections may be adapted to the subsurface configuration and imaging objectives by modifying the spacing of the sounding mid-points and by adding/removing/shifting individual resistivity measurements. Simulations with synthetic resistivity models may be run with R2 to predict the response of the acquisition system to expected subsurface configurations; based on this response, the acquisition settings may be optimised. The versatility of the methodology to allow optimal characterization and adaptive investigation of local aquifer potential is hence high.

\subsubsection{Operational Performance}

Acquisition of the surveys during the four weeks dedicated to surveying activities was limited by the availability of vehicles over 10 days in total, during which the four resistivity surveys were acquired. Soundings were acquired one day by a single operator, and the rest of the days by a crew of three or four operators. A single experienced operator could acquire four soundings in $8 \mathrm{~h}$, working at a fast pace. A crew of three or four trained operators could acquire four soundings in $6 \mathrm{~h}$, working at a moderate pace: Such values are commensurate with the speed of conventional VES acquisitions, which require at least three operators to achieve around four soundings per day. Whilst operational efficiency of the resistivity method implemented is significantly inferior to that of 2-D surface ERT, it is still perfectly acceptable, especially in developing-world contexts.

\subsection{Potential for Technology Deployment}

\subsubsection{Applications}

The resistivity technology implemented may be deployed in Malawi as a standalone operation for fundamental hydrogeological research. For instance, a collaborative programme of use by a Malawian university consortium with the Ministry could regionally better characterise groundwater bodies and their aquifer potential than has hitherto been possible. The most powerful technology application foreseen though is its integration to Water and Sanitation Hygiene (WASH) borehole drilling programmes. Technology applications of significance include the following:

- Integration with drilling: The most important application in Malawi would be assisting improved siting of supply boreholes. It may also help identify lithologies, faults and fractures, and thereby would help anticipate the mechanical behaviour of formations to be drilled and aid optimal selection of drilling methods.

- Integration with other surface geophysics: Combined deployment with MP may be beneficial, as, although only qualitative answers are provided by MP about the subsurface configuration, it may still enable the identification of lineaments or help distinguish lithologies with different magnetic signatures that may appear similar on resistivity cross-sections. There is no benefit associated with combining the resistivity method implemented with conventional VES or EMP used in Malawi.

- Integration with borehole logging: Borehole-scale geological calibration and validation of the geophysical survey section (not possible in the current study due to a lack of nearby logged boreholes) will increase confidence in its geological interpretation and predictive use. Geomechanical parameters of drilled formations (hardness, stiffness, abrasivity, etc.) may be compared to resistivity cross-sections, to check for any correlations. Drill-cutting analyses and borehole CCTV image may help identify geological features too small or of insufficient contrast to be identified by resistivity. They may help identify unexplained features observed on resistivity cross-sections and whether transitions are real or artefacts of inversion smoothing. Conversely, large-scale features 
on cross-sections may help interpret much smaller-scale drill cutting or CCTV image observations.

- Integration with aquifer testing: Aquifer shape and dimensions, presence and continuity of confining units and aquifer boundaries, and aquifer heterogeneity and zonation are critical parameters to inform the analysis of aquifer pumping test data and may all be determined on the resistivity cross-sections. Likewise, pumping test and borehole rest water-level measurements permit more quantitative hydrogeological conceptualisation of the resistivity section.

In relation to achieving the UN's SDG Target 6.1 [4], technology application may assist the Government of Malawi's current ambition is to improve the rural drinking water service from a basic level of service, currently focused on hand-pumped boreholes albeit with functionality concerns [5-7], to a safely managed level. Plans for larger groundwater supply projects involving solar powered submersible pumps from multiple borehole "well fields" feeding reticulated piped networks will need to be supported by advanced geophysical subsurface imaging reconnaissance with tools such as that implemented that are viable in developing country settings.

\subsubsection{Hardware and Software Requirements}

The resistivity method implemented may be applied using standard VES equipment (here, an ERT unit was used but only in VES mode (as no VES unit was available) and a multi-cable system was used but only to allow VES acquisition when less than three operators are available). Using a VES unit in combination with either a standard VES cable set or a "do it yourself" multi-cable system (as developed herein) is a low-cost alternative to using expensive ERT equipment for performing true 2-D subsurface resistivity surveys. The Ministry in Malawi possesses VES units and cables and an ERT unit but without cables. Adoption of the resistivity method implemented would allow the Ministry to undertake true 2-D subsurface resistivity surveys without having to acquire expensive ERT cables. The multi-cable system developed could be enhanced with the addition of a switchbox (with components costing under (GBP) £100) connected to the resistivity unit directly or via a VES adapter [51]. This would eliminate the need to disconnect and reconnect cables between individual resistivity measurement reducing operation time.

For non-commercial activities (e.g., not-for-profit research), resistivity inversion may be carried out using freeware R2. Otherwise, commercial 2-D inversion software would have to be used. Cross-section display may be carried out by using freeware ParaView without restrictions on commercial use.

\subsubsection{Capacity Building}

The preparation, processing and interpretation of resistivity surveys with the method implemented in this study require advanced skills: (i) a solid knowledge of the local geology and hydrogeology, to perform appropriate survey preparations and valid interpretations; (ii) a sound understanding of measurement physics, to be able to anticipate and explain subsurface resistivity responses; and (iii) an ability to write complex command files for software R2. Any gaps in these skills among the Malawian hydrogeologists or geophysicists (or other professionals) may be addressed through training, ideally via a combination of field work, lectures and workshops. Training should cover implementing technicians to reduce occurrence of common mistakes made in instrument calibration, method execution, hardware treatment (e.g., cable shortening) and data handling and processing. Ideally, too, training would rapidly evolve from international external delivery to in-house delivery via Malawian user organizations, i.e., trained Malawian university research users, start-up user companies established in Malawi assisting WASH drilling programmes and/or users or data decision makers in the Ministry. 


\section{Conclusions}

The hydrogeophysical survey technology successfully developed and demonstrated at four contrasting sites in Malawi was designed to be low cost, easy to use, efficient and accessible to developing countries. The technology uses multiple vertical electrical soundings (VESs) to generate a true 2-D resistivity image of the geological subsurface complexity that successfully distinguishes a wide range of (hydro)geological features having an imaging performance that appears comparable to that of the much more expensive 2-D surface ERT. The technology is vastly superior to 1-D hydrogeophysical reconnaissance tools currently employed in Malawi to aid borehole siting. Its adoption could make valuable use of existing VES equipment and knowhow already present, and overcome ERT affordability issues. There is, hence, significant opportunity for technology deployment in Malawi. This is under discussion nationally. Widespread application would allow much improved targeting of local aquifer resource, more optimal and sustainable siting of boreholes and hence greater resilience of Malawi's rural water-supply infrastructure, thereby underpinning attainment of SDG 6 targets. Technology application to the wider developing world is perceived useful, especially where current hydrogeophysical reconnaissance methods are lacking and (hydro)geological complexities are more probable.

Supplementary Materials: The following are available online at https:/ / www.mdpi.com/2076-3 417/11/3/1162/s1. Figure S1: Geological map of Malawi. Box S1: Practical construction details of the VES cable system used. Table S1: Sequence of electrode combinations for the acquisition of resistivity measurements. Figure S2: Series of fully collinear soundings for 2-D surveys. Figure S3: General sequence of acquisition and measurement parameter settings for surveys. Table S2: Details of input files for resistivity inversion freeware R. Figure S4: Example quadrilateral mesh used for resistivity inversions. Figure S5: Muzongo survey: preliminary interpreted subsurface resistivity cross-section AB (final interpretation is made in Figure 9). Figure S6: Sedimentary environments interpreted from the Chiluwe outcrop analyses. The geophysical survey data presented are provided in the file: Geophysical survey - field results.

Author Contributions: Conceptualization, R.L., R.M.K., M.O.R. and P.S.; methodology, R.L., P.S. and R.M.K.; software, R.L.; validation, R.L., and M.O.R.; formal analysis, R.L.; investigation, R.L. and G.J.W.; resources, P.S., G.J.W. and R.M.K.; data curation, R.L.; writing-original draft preparation, R.L., and M.O.R.; writing-review and editing, M.O.R., R.M.K., P.S., R.L. and G.J.W.; visualization, R.L. and M.O.R.; supervision, R.M.K. and P.S.; project administration, R.M.K.; funding acquisition, R.M.K. All authors have read and agreed to the published version of the manuscript.

Funding: This research was funded by research by the Scottish Government, under the Scottish Government Climate Justice Fund Water Futures Programme (CJF) research grant HN-CJF-03, awarded to the University of Strathclyde (R.M. Kalin).

Institutional Review Board Statement: Not applicable.

Informed Consent Statement: Not applicable.

Data Availability Statement: The geophysical survey data presented in this study are provided in the Supplementary Materials.

Acknowledgments: We acknowledge the support of Nick Mannix, Jamie Rattray and Shaun MacLeod, all formerly of the University of Strathclyde, in the planning and execution of the geophysical survey fieldwork in Malawi. Andrew Binley of University of Lancaster is thanked for the provision of the R2 software.

Conflicts of Interest: The authors declare no conflict of interest.

\section{References}

1. Carter, R.C. Long Live the Humble Handpump. In Proceedings of the 42nd Congress of the International Association of Hydrogeologists, Rome, Italy, 13-18 September 2015; Presentation 168, Session S1.1a. Available online: https://upgro.files. wordpress.com/2015/09/carter-id-n168-session-s1-1a.pdf (accessed on 25 November 2020).

2. Pavelic, P.; Giordano, M.; Keraita, B.; Ramesh, V.; Rao, T. (Eds.) Groundwater Availability and Use in Sub-Saharan Africa: A Review of Fifteen Countries; International Water Management Institute: Colombo, Sri Lanka, 2012. [CrossRef] 
3. Howard, G.; Calow, R.; MacDonald, A.; Bartram, J. Climate change and water and sanitation: Likely impacts and emerging trends for action. Ann. Rev. Environ. Resourc. 2016, 41, 253-276. [CrossRef]

4. WHO \& UNICEF. Progress on Drinking Water, Sanitation and Hygiene: 2017 Update and SDG Baselines, Geneva: WHO/UNICEF Joint Monitoring Program; World Health Organization: Geneva, Switzerland, 2017. Available online: https://www.who.int/water_ sanitation_health/publications/jmp-2017/en/ (accessed on 9 December 2019).

5. Truslove, J.P.; Miller, A.V.M.; Mannix, N.; Nhlema, M.; Rivett, M.O.; Coulson, A.B.; Mleta, P.; Kalin, R.M. Understanding the functionality and burden on decentralised rural water supply: Influence of Millennium Development Goal 7c coverage targets. Water 2019, 11, 494. [CrossRef]

6. Kalin, R.M.; Mwanamveka, J.; Coulson, A.B.; Robertson, D.J.C.; Clark, H.; Rathjen, J.; Rivett, M.O. Stranded Assets as a key concept to guide investment strategies for Sustainable Development Goal 6. Water 2019, 11, 702. [CrossRef]

7. Mkandawire, T.; Mwathunga, E.; MacDonald, A.M.; Bonsor, H.C.; Banda, S.; Mleta, P.; Jumbo, S.; Ward, J.; Lapworth, D.; Chavula, G.; et al. An analysis of hand pump boreholes functionality in Malawi. Phys. Chem. Earth Parts A/B/C 2020, $118,102897$. [CrossRef]

8. Foster, T. Predictors of Sustainability for Community-Managed Handpumps in Sub-Saharan Africa: Evidence from Liberia, Sierra Leone, and Uganda. Environ. Sci. Technol. 2013, 47, 12037-12046. [CrossRef]

9. Goldberg, J.; Brocklehurst, C. Detailed Review of a Recent Publication: Getting Handpump Functionality Monitoring Right Can Ensure Rural Water Supply Sustainability. In WaSH Policy Research Digest \#3; UNC (University of North Carolina) Water Institute: Chapel Hill, NC, USA, 2016. Available online: https:/ / waterinstitute.unc.edu/files/2016/03/wash-policy-research-digest-3.pdf (accessed on 25 November 2020).

10. Mannix, N.; Norrie, J.; Paterson, F.; Nhlema, M.; Mleta, P.; Nkhata, M.; Wanangwa, G.; Kumwenda, S.; Clarke, D.; Kalin, R.M. Making the Case for Improved Planning, Construction and Testing of Water Supply Infrastructure in Malawi. In Transformation towards Sustainable and Resilient WASH Services, Proceedings of the 41st WEDC International Conference, Nakuru, Kenya, 9-13 July 2018; Egerton University: Nakuru, Kenya, 2018.

11. Bonsor, H.C.; Oates, N.; Chilton, P.J.; Carter, R.C.; Casey, V.; MacDonald, A.M.; Calow, R.; Alowo, R.; Wilson, P.; Tumutungire, M.; et al. A Hidden Crisis: Strengthening the Evidence Base on the Sustainability of Rural Groundwater Supplies-Results from a Pilot Study in Uganda; OR/15/019; British Geological Survey: Nottingham, UK, 2015. Available online: http://nora.nerc.ac.uk/id/eprint/51 1071/ (accessed on 3 April 2019).

12. Wright, E.P. The hydrogeology of crystalline basement aquifers in Africa. Geol. Soc. Lond. Spec. Publ. 1992, 66, 1-27. [CrossRef]

13. Chilton, P.; Foster, S. Hydrogeological characterisation and water-supply potential of basement aquifers in tropical Africa. Hydrogeol. J. 1995, 3, 36-49. [CrossRef]

14. Smith-Carington, A.K.; Chilton, P.J. Groundwater Resources of Malawi; Overseas Development Administration Institute of Geological Sciences: London, UK, 1983. Available online: http://resources.bgs.ac.uk/sadcreports/malawi198 3smithcarringtonmalawigwresources.pdf (accessed on 8 October 2019).

15. Upton, K.; Dochartaigh, B.É.Ó.; Chunga, B.; Bellwood-Howard, I. Africa Groundwater Atlas: Hydrogeology of Malawi, 2018, British Geological Survey. Available online: http:/ / earthwise.bgs.ac.uk/index.php/Hydrogeology_of_Malawi (accessed on 10 April 2020).

16. Council for Geoscience. Consultancy Services for National Hydrogeological and Water Quality Mapping: Final Geophysical Survey Report; Ministry of Agriculture, Irrigation and Water Development of Malawi: Lilongwe, Malawi, 2015.

17. Council for Geoscience. Hydrogeological and Water Quality Mapping Consultancy in the Shire River Basin: Final Geophysical Survey Report; Ministry of Agriculture, Irrigation and Water Development of Malawi Lilongwe: Lilongwe, Malawi, 2017.

18. Wanangwa, G.J.; Colleagues with geophysical survey expertise. (Ministry of Irrigation and Water Development of Malawi, Lilongwe, Malawi). Personal communication, 2019.

19. Nkhata, M.G.M.; Manda, B.; Saka, J.D.K.; Aagaard, P.; Monjerezi, M. Vertical trends and distribution of salinity in geological strata in Lower Shire Valley, Malawi using vertical electrical sounding and geochemical analyses. Int. J. Water Res. 2020, 2, 1-9.

20. Alle, I.C.; Descloitres, M.; Vouillamoz, J.M.; Yalo, N.; Lawson, F.M.; Adihou, A.C. Why 1 D electrical resistivity techniques can result in inaccurate siting of boreholes in hard rock aquifers and why electrical resistivity tomography must be preferred: The example of Benin, West Africa. J. Afr. Earth Sci. 2018, 139, 341-353. [CrossRef]

21. Acworth, I. The electrical image method compared with resistivity sounding and electromagnetic profiling for investigation in areas of complex geology: A case study from groundwater investigation in a weathered crystalline rock environment. Explor. Geophys. 2001, 32, 119-128. [CrossRef]

22. Kellett, R.; Steensma, G.; Bauman, P. Mapping Groundwater in Regolith and Fractured Bedrock Using Ground and Airborne Geophysics: Case Studies from Malawi and Brazil. In Proceedings of the 17th ASEG-PESA Geophysical Conference, Sydney, Australia, 15-19 August 2004.

23. Kumar, D.; Ahmed, S.; Krishnamurthy, N.S.; Dewandel, B. Reducing ambiguities in vertical electrical sounding interpretation: A geostatistical application. J. Appl. Geophys. 2007, 62, 16-32. [CrossRef]

24. Council for Geoscience. Consultancy Services for the Shire Basin Hydrogeological and Water Quality Mapping: Exploratory Drilling Report; Ministry of Agriculture, Irrigation and Water Development of Malawi: Lilongwe, Malawi, 2018.

25. Wanangwa, G.J.; Colleagues with well drilling expertise. (Ministry of Irrigation and Water Development of Malawi, Lilongwe, Malawi). Personal communication, 2019. 
26. Griffiths, D.H.; Turnbull, J. A multi-electrode array for resistivity surveying. First Break 1985, 3, 16-20. [CrossRef]

27. Griffiths, D.H.; Barker, R.D. Two-dimensional resistivity imaging and modeling in areas of complex geology. J. Appl. Geophys. 1993, 29, 211-226. [CrossRef]

28. Gao, Q.; Shang, Y.; Hasan, M.; Jin, W.; Yang, P. Evaluation of a weathered rock aquifer using ERT method in South Guangdong, China. Water 2018, 10, 293. [CrossRef]

29. Marzan, I. Geophysical Survey for Water Persepectives in an Arid Pastoral-Agropastoral Context: Zone 1 Afar Region in Ethiopia, s.l.: Action Contre la Faim. 2005. Available online: https:/ / www.geotomosoft.com/Afar2005.pdf (accessed on 25 January 2021).

30. Ramachandran, K.; Tapp, B.; Rigsby, T.; Lewallen, E. Imaging of fault and fracture controls in the Arbuckle-Simpson Aquifer, southern Oklahoma, USA, through electrical resistivity sounding and tomography methods. Int. J. Geophys. 2012, 5, 184836. [CrossRef]

31. Okoro, E.I.; Egboka, B.C.; Onwuemesi, A.G. Evaluation of the aquifer characteristic of Nanka Sands using hydrogeological method in combination with Vertical Electrical Sounding (VES). J. Appl. Sci. Environ. Manag. 2010, 14, 5-9. [CrossRef]

32. Song, L.; Zhu, J.; Yan, Q.; Kang, H. Estimation of groundwater levels with vertical electrical sounding in the semiarid area of South Keerqin sandy aquifer, China. J. Appl. Geophys. 2012, 83, 11-18. [CrossRef]

33. González, J.A.; Comte, J.C.; Legchenko, A.; Ofterdinger, U.; Healy, D. Quantification of groundwater storage heterogeneity in weathered/fractured basement rock aquifers using electrical resistivity tomography: Sensitivity and uncertainty associated with petrophysical modelling. J. Hydrol. 2020, 125637. [CrossRef]

34. Mohammed, M.A.; Senosy, M.M.; Abudeif, A.M. Derivation of empirical relationships between geotechnical parameters and resistivity using electrical resistivity tomography (ERT) and borehole data at Sohag University site, upper Egypt. J. Afr. Earth Sci. 2019, 158, 103563. [CrossRef]

35. Ullah, S.; Zhou, B.; Iqbal, M.A. A novel electrode array for resistivity imaging to assess groundwater resource: Field test. J. Environ. Eng. Sci. 2020, 15, 197-207. [CrossRef]

36. Mukhwathi, U.; Fourie, F. The influence of angled survey lines on 2D ERT surveys using the Wenner $(\alpha)$ array with implications for groundwater exploration in Karoo rocks. J. Afr. Earth Sci. 2020, 103875. [CrossRef]

37. Loke, M.H.; Chambers, J.E.; Rucker, D.F.; Kuras, O.; Wilkinson, P.B. Recent developments in the direct-current geoelectrical imaging method. J. Appl. Geophys. 2013, 95, 135-156. [CrossRef]

38. Asfahani, J. Quaternary aquifer transmissivity derived from vertical electrical sounding measurements in the semi-arid Khanasser valley region, Syria. Acta Geophysica 2012, 60, 1143-1158. [CrossRef]

39. Chandra, S.; Ahmed, S.; Rangarjan, R. Lithologically constrained rainfall (LCR) for estimating spatio-temporal recharge distribution in crystalline rocks. J. Hydrol. 2011, 402, 250-260. [CrossRef]

40. Ekwe, A.C.; Nnodu, I.N.; Ugwumbah, K.I.; Onwuka, O.S. Estimation of aquifer hy-draulic characteristics of low permeability formation from geoounding data: A casestudy of Oduma Town, Enugu State. Online J. Earth Sci. 2010, 4, 19-26. [CrossRef]

41. Khalil, M.H. Hydro-geophysical configuration for the quaternary aquifer of Nuweiba Alluvial Fan. J. Environ. Eng. Geophys. 2010, 15, 77-90. [CrossRef]

42. Barseem, M.S. Geoelectrical investigation using $1 \mathrm{D}$ and $2 \mathrm{D}$ techniques to delineate the groundwater occurrence condition in $\mathrm{Al}$ Gorah and its vacinities-Northeastern Sinai-Egypt. Egypt. J. Geol. 2016, 60, 61-74.

43. Gouet, D.H.; Meying, A.; Ekoro Nkoungou, H.L.; Assembe, S.P.; Njandjock Nouck, P.; Ndougsa Mbarga, T. Typology of sounding curves and lithological 1D models of mineral prospecting and groundwater survey within crystalline basement rocks in the East of Cameroon (Central Africa) using electrical resistivity method and Koefoed computation method. Int. J. Geophys. 2020, 2020, 8630406. [CrossRef]

44. Manu, E.; Agyekum, W.A.; Duah, A.A.; Tagoe, R.; Preko, K. Application of vertical electrical sounding for groundwater exploration of Cape Coast municipality in the Central Region of Ghana. Arab. J. Geosci. 2019, 12, 196. [CrossRef]

45. Rusydy, I.; Setiawan, B.; Zainal, M.; Idris, S.; Basyar, K.; Putra, Y.A. Integration of borehole and vertical electrical sounding data to characterise the sedimentation process and groundwater in Krueng Aceh basin, Indonesia. Groundw. Sustain. Dev. 2020, 10, 100372. [CrossRef]

46. Leite, D.N.; Bortolozo, C.A.; Porsani, J.L.; Couto, M.A., Jr.; Campaña, J.D.; dos Santos, F.A.; Rangel, R.C.; Hamada, L.R.; Sifontes, R.V.; de Oliveira, G.S.; et al. Geoelectrical characterization with 1D VES/TDEM joint inversion in Urupês-SP region, Paraná Basin: Applications to hydrogeology. J. Appl. Geophys. 2018, 151, 205-220. [CrossRef]

47. Kellett, R.; Bauman, P. Mapping groundwater in regolith and fractured bedrock using ground geophysics: A case study from Malawi, SE Africa. Can. Soc. Explor. Geophys. Rec. 2004, 2, 24-33.

48. Muchingami, I.; Chuma, C.; Gumbo, M.; Hlatywayo, D.; Mashingaidze, R. Review: Approaches to groundwater exploration and resource evaluation in the crystalline basement aquifers of Zimbabwe. Hydrogeol. J. 2019, 27, 915-928. [CrossRef]

49. Cheal, R. An Evaluation of Basic Geophysical and Borehole Logging Approaches for Improving Borehole Placement and Wellbore Construction: A Case Study Examining a Saline-Contaminated Fluvial Aquifer in Southern Malawi. Master's Thesis, University of Strathclyde, Glasgow, UK, 2014.

50. Mohamaden, M.I.I.; Ehab, D. Application of electrical resistivity for groundwater exploration in Wadi Rahaba, Shalateen, Egypt. NRIAG J. Astron. Geophys. 2017, 6, 201-209. [CrossRef]

51. Leborgne, R. True 2-D Resistivity Imaging from Vertical Electrical Soundings: Application to Groundwater Investigations in Malawi. Master's Thesis, Department of Civil and Environmental Engineering, University of Strathclyde, Glasgow, UK, 2019. 
52. Atzemoglou, A.; Tsourlos, P. 2D interpretation of vertical electrical soundings: Application to the Sarantaporon basin (Thessaly, Greece). J. Geophys. Eng. 2011, 9, 50-59. [CrossRef]

53. Khalil, M.A.; Monteiro Santos, F.A. 2D resistivity inversion of 1D electrical-sounding measurements in deltaic complex geology: Application to the delta Wadi El-Arish, Northern Sinai, Egypt. J. Geophys. Eng. 2011, 8, 422-433. [CrossRef]

54. Massoud, U.; Soliman, M.; Taha, A.; Khozym, A.; Salah, H. 1D and 3D inversion of VES data to outline a fresh water zone floating over saline water body at the northwestern coast of Egypt. NRIAG J. Astron. Geophysics 2015, 4, 283-292. [CrossRef]

55. Hertrich, M.; Yaramanci, U. Joint inversion of surface nuclear magnetic resonance and vertical electrical sounding. J. Appl. Geophys. 2002, 50, 179-191. [CrossRef]

56. Perttu, N.; Wattanasen, K.; Phommasone, K.; Elming, S.A. Characterization of aquifers in the Vientiane Basin, Laos, using magnetic resonance sounding and vertical electrical sounding. J. Appl. Geophys. 2011, 73, 207-220. [CrossRef]

57. The World Bank Data. Malawi. Available online: https://data.worldbank.org/country/malawi?view=chart (accessed on 20 July 2019).

58. The World Bank Data. Population Density. Available online: https://data.worldbank.org/indicator/EN.POP.DNST?most_ recent_year_desc=true (accessed on 20 July 2019).

59. The World Bank. The World Bank in Malawi. Available online: https://www.worldbank.org/en/country/malawi/overview (accessed on 20 July 2019).

60. Banda, L.C.; Rivett, M.O.; Kalin, R.M.; Zavison, A.S.K.; Phiri, P.; Kelly, L.; Chavula, G.; Kapachika, C.C.; Nkhata, M.; Kamtukule, S.; et al. 2019. Water-isotope capacity building and demonstration in a developing world context: Isotopic baseline and conceptualization of a Lake Malawi catchment. Water 2019, 11, 2600. [CrossRef]

61. Rivett, M.O.; Budimir, L.; Mannix, N.; Miller, A.V.M.; Addison, M.J.; Moyo, P.; Wanangwa, G.J.; Phiri, O.L.; Songola, C.E.; Nhlema, M.; et al. Responding to salinity in a rural African alluvial valley aquifer system: To boldly go beyond the world of hand-pumped groundwater supply? Sci. Total Environ. 2019, 653, 1005-1024. [CrossRef] [PubMed]

62. Rivett, M.O.; Symon, S.; Jacobs, L.; Banda, L.C.; Wanangwa, G.J.; Robertson, D.J.C.; Hassan, I.; Miller, A.V.M.; Chavula, G.M.S.; Songola, C.E.; et al. Paleo-geohydrology of Lake Chilwa, Malawi is the source of localised groundwater salinity and rural water supply challenges. Appl. Sci. 2020, 10, 6909. [CrossRef]

63. Thatcher, E.C. The Geology of the Dedza Area; Malawi Government: Zomba, Malawi, 1969.

64. Peel, M.C.; Finlayson, B.L.; McMahon, T.A. Updated world map of the Koppen-Geiger climate classification. Hydrol. Earth Syst. Sci. 2007, 11, 1633-1644. [CrossRef]

65. Watkins, D. 30-Meter SRTM Tile Downloader. 2019. Available online: https:/ /dwtkns.com/srtm30m/ (accessed on 7 February 2019).

66. Hughes, A.G.; Matumbi, P.E. Geological Atlas of Malawi, 1st ed.; Sheet 4; British Government's Overseas Development Administration: London, UK, 1972.

67. Carter, G.S.; Bennett, J.D. The Geology and Mineral Resources of Malawi. Bull. Geol. Surv. Malawi 1973, 6, 1-62.

68. GMS and HydroConsult. Consultancy Services for Assessment and Mapping of Groundwater Sources for Lilongwe City; Lilongwe Water Board: Lilongwe, Malawi, 2019.

69. Ring, U. Aspects of the kinematic history and mechanisms of superposition of the proterozoic mobile belts of eastern Central Africa (northern Malawi and southern Tanzania). Precamb. Res. 1993, 62, 207-226. [CrossRef]

70. Fagereng, A. Fault segmentation, deep rift earthquakes and crustal rheology: Insights from the 2009 Karonga sequence and seismicity in the Rukwa-Malawi rift zone. Tectonophysics 2013, 601, 216-225. [CrossRef]

71. Lister, L.A. Erosion surfaces in Malawi. Rec. Geol. Surv. Malawi 1965, 7, 15-28.

72. ArcGIS. Landsat 8 Imagery: Geology with DRA. Available online: https://www.arcgis.com/home/webmap/viewer.html? layers=9f9d2f7b6460497c9cbb9548d4ec0bc8 (accessed on 12 June 2019).

73. MoAIWD (Ministry of Agriculture, Irrigation and Water Development). Malawi Hydrogeological and Water Quality Atlas; Ministry of Agriculture, Irrigation and Water Development of Malawi: Lilongwe, Malawi, 2018.

74. Acworth, R.I. The development of crystalline basement aquifers in a tropical environment. Q. J. Eng. Geol. 1987, $20,265-272$. [CrossRef]

75. Chilton, P.J.; Smith-Carington, A.K. Characteristics of the Weathered Basement Aquifer in Malawi in Relation to Rural Water Supplies; Challenges in African Hydrology and Water Resources (Proceedings of the Harare Symposium, July 1984); IAHS Publ: Wallingford, UK, 1984; Volume 44, pp. 57-72. Available online: http:/ /hydrologie.org/redbooks/a144/iahs_144_0057.pdf (accessed on 25 November 2020).

76. Davies, J.; Farr, J.L.; Robins, N.S. Is the Precambrian Basement Aquifer in Malawi up to the Job? In Assessing and Managing Groundwater in Different Environments; Cobbing, J., Adams, S., Dennis, I., Riemann, K., Eds.; CRC Press: Boca Raton, FL, USA, 2013; pp. 241-250.

77. Mäckel, R. Dambos: A study in morphodynamic activity on the plateau regions of Zambia. Catena 1973, 1, 327-365. [CrossRef]

78. GF Instruments. ARES—Automatic Resistivity System. Available online: http://www.gfinstruments.cz/index.php?menu= giandsmenu=iresandcont=ares_andear=ov (accessed on 30 July 2019).

79. Dahlin, T. Short note on electrode charge-up effects in DC resistivity data acquisition using multi-electrode arrays. Geophys. Prospect. 2000, 48, 181-187. [CrossRef]

80. Microsoft. Bing Maps. Available online: https://www.bing.com/maps / (accessed on 2 June 2019). 
81. QGIS Development Team. Download QGIS. Available online: https://www.qgis.org/en/site/forusers/download.html (accessed on 10 January 2019).

82. Binley, A. R2 Version 3.3 (March 2019); Lancaster University: Lancaster, UK, 2019; 40p.

83. Kitware. ParaView: Welcome to ParaView. Available online: https://www.paraview.org/ (accessed on 19 July 2019).

84. Whitney, D.L.; Teyssier, C.; Vanderhaege, O. Gneiss Domes and Crustal Flow; Geological Society of America: Boulder, CL, USA, 2004; Special paper 380. 